\title{
Seasonal variability of NOx emissions over east China constrained by satellite observations: Implications for combustion and microbial sources
}

\section{Citation}

Wang, Yuxuan, Michael B. McElroy, Randall V. Martin, David G. Streets, Qiang Zhang, and TungMay Fu. 2007. "Seasonal Variability of NOx Emissions over East China Constrained by Satellite Observations: Implications for Combustion and Microbial Sources." Journal of Geophysical Research 112 (D6) (March 16). doi:10.1029/2006jd007538.

\section{Published Version}

doi:10.1029/2006JD007538

\section{Permanent link}

http://nrs.harvard.edu/urn-3:HUL.InstRepos:28346358

\section{Terms of Use}

This article was downloaded from Harvard University's DASH repository, and is made available under the terms and conditions applicable to Other Posted Material, as set forth at http:// nrs.harvard.edu/urn-3:HUL.InstRepos:dash.current.terms-of-use\#LAA

\section{Share Your Story}

The Harvard community has made this article openly available.

Please share how this access benefits you. Submit a story.

Accessibility 


\title{
Seasonal variability of $\mathrm{NO}_{\mathrm{x}}$ emissions over east China constrained by satellite observations: Implications for combustion and microbial sources
}

\author{
Yuxuan Wang, ${ }^{1}$ Michael B. McElroy, ${ }^{1}$ Randall V. Martin, ${ }^{2,3}$ David G. Streets, ${ }^{4}$ \\ Qiang Zhang, ${ }^{4}$ and Tung-May Fu ${ }^{1}$ \\ Received 21 May 2006; revised 29 August 2006; accepted 2 November 2006; published 16 March 2007.
}

[1] Observations of tropospheric column densities of $\mathrm{NO}_{2}$ obtained from the Global Ozone Monitoring Experiment (GOME) for a 3-year period (1997, 1998, and 2000) are used to derive average seasonal variations in surface emissions of $\mathrm{NO}_{\mathrm{x}}$ from east China $\left(100-123^{\circ} \mathrm{E}, 20-42^{\circ} \mathrm{N}\right)$. The retrieval allows for zonal variations in the contribution of the stratosphere to the $\mathrm{NO}_{2}$ column and removes a bias of $\pm 10 \%$ on the seasonality of retrieved columns introduced by cloud screening. The top-down inventory is constructed using an inversion approach with a global 3-D chemical transport model (GEOS-Chem) and combined subsequently with the a priori inventory to develop an a posteriori inventory. The contribution of background $\mathrm{NO}_{2}$ arising from nonsurface sources (lightning) and long-range transport of emissions originating outside of east China is accounted for in the inversion. The a posteriori estimate of overall emissions for east China, $4.66 \mathrm{Tg} \mathrm{N} / \mathrm{yr}( \pm 30 \%$ uncertainty), is $33 \%$ higher than the a priori value and is shown to improve agreement with surface measurements of nitrate wet deposition and concentrations of $\mathrm{NO}_{\mathrm{y}}$ observed in China. On the basis of multiple constraints on the spatial and seasonal variations of combustion and microbial processes, the a posteriori inventory is partitioned among emissions from biomass burning, fuel combustion, and microbial activity (or soil emissions). Emission of $\mathrm{NO}_{\mathrm{x}}$ from biomass burning in east China is estimated as $0.08 \mathrm{TgN} / \mathrm{yr} \pm 50 \%$ in the a posteriori inventory, increased by about a factor of 2 from the a priori estimate. The resulting a posteriori inventory for fuel combustion $(3.72 \mathrm{TgN} / \mathrm{yr} \pm 32 \%)$ is about $15 \%$ higher than the a priori and exhibits a distinct maximum in winter, in contrast to the weak seasonality indicated in the a priori inventory. The a posteriori value for the microbial source of $\mathrm{NO}_{\mathrm{x}}(0.85 \mathrm{TgN} / \mathrm{yr} \pm 40 \%)$ is about a factor of 3 higher than the a priori value, amounting to $23 \%$ of combustion sources for east China and significantly higher than a priori value of $7 \%$. The microbial source is unimportant in winter. It peaks in summer, accounting for as much as $43 \%$ of the combustion source for that season, and is significant also in spring and fall. This seasonality is attributed to the timing of fertilizer application and to the influence of seasonally variable environmental factors including temperature and precipitation.

Citation: Wang, Y., M. B. McElroy, R. V. Martin, D. G. Streets, Q. Zhang, and T.-M. Fu (2007), Seasonal variability of NO emissions over east China constrained by satellite observations: Implications for combustion and microbial sources, J. Geophys. Res., 112, D06301, doi:10.1029/2006JD007538.

\footnotetext{
${ }^{1}$ Division of Engineering and Applied Sciences and Department of Earth and Planetary Sciences, Harvard University, Cambridge, Massachusetts, USA.

${ }^{2}$ Department of Physics and Atmospheric Science, Dalhousie University, Halifax, Nova Scotia, Canada.

${ }^{3}$ Also at Atomic and Molecular Physics Division, Harvard-Smithsonian Center for Astrophysics, Cambridge, Massachusetts, USA.

${ }^{4}$ Decision and Information Sciences Division, Argonne National Laboratory, Argonne, Illinois, USA.
}

Copyright 2007 by the American Geophysical Union. 0148-0227/07/2006JD007538

\section{Introduction}

[2] Production of ozone $\left(\mathrm{O}_{3}\right)$ in the troposphere is controlled in large measure by the abundance of nitrogen oxides $\left(\mathrm{NO}_{\mathrm{x}} \equiv \mathrm{NO}+\mathrm{NO}_{2}\right)$. Nitrogen oxides also have both a direct and indirect influence on the abundance of hydroxyl $(\mathrm{OH})$ radicals, regulating thus the lifetime of a number of key pollutants and greenhouse gases (e.g., $\mathrm{CO}$ and $\mathrm{CH}_{4}$ ). Sources of $\mathrm{NO}_{\mathrm{x}}$ in the troposphere include combustion of fossil and biofuels, biomass burning, lightning, and bacterially mediated decomposition of nitrogen processed through the agriculture/animal/human food chain (we refer to this as the microbial source in what follows) [Logan, 
1983]. Reaction with $\mathrm{OH}$ to form nitric acid $\left(\mathrm{HNO}_{3}\right)$ provides the dominant sink of tropospheric $\mathrm{NO}_{\mathrm{x}}$ during daytime, while reaction with $\mathrm{O}_{3}$ followed by hydrolysis of $\mathrm{N}_{2} \mathrm{O}_{5}$ on aerosols is the major sink at night [Dentener and Crutzen, 1993; Jacob, 2000]. $\mathrm{NO}_{2}$ is removed from the atmosphere also by dry deposition. The overall lifetime for $\mathrm{NO}_{\mathrm{x}}$ in the boundary layer varies from a few hours in the tropics to a couple of days at midlatitudes in winter [Leue et al., 2001; Martin et al., 2003a].

[3] Understanding of $\mathrm{NO}_{\mathrm{x}}$ sources has been developed largely using the "bottom-up" approach by which combustion sources are estimated on the basis of fuel consumption data for specific industrial and human activities, combined subsequently with activity-specific emission factors. The bottom-up combustion inventories for large developing countries such as China are subject to errors resulting from deficiencies in available energy statistics and emission factors [Sinton and Fridley, 2000]. The microbial source for $\mathrm{NO}_{\mathrm{x}}$ has been estimated using process-oriented agroecosystem models [Potter et al., 1996] and by extrapolation in space and time of field measurements of surface fluxes [Logan, 1983; Lee et al., 1997]. Given the sensitivity of microbial activity to environmental conditions [Hall et al., 1996], it is difficult to estimate the global microbial source of $\mathrm{NO}_{\mathrm{x}}$ in a "bottom-up" approach absent sufficient understanding of the processes and an extensive database of NO yields (or fluxes) covering a variety of diverse environmental conditions.

[4] Space-based observations of $\mathrm{NO}_{2}$ provide an important new source of data offering both global and year-round coverage. This paper describes a reanalysis of observations of $\mathrm{NO}_{2}$ columns inferred from the Global Ozone Monitoring Experiment (GOME) instrument, developing "top-down" estimates for the seasonal variation of $\mathrm{NO}_{\mathrm{x}}$ emissions over east China $\left(100-123^{\circ} \mathrm{E}\right.$ and $\left.20-42^{\circ} \mathrm{N}\right)$ where the tropospheric contribution dominates in the total $\mathrm{NO}_{2}$ column. Tropospheric $\mathrm{NO}_{2}$ columns are linked to emissions using information on the lifetime of $\mathrm{NO}_{\mathrm{x}}$ and the ratio $\mathrm{NO}_{2} / \mathrm{NO}_{\mathrm{x}}$ obtained from a global three-dimensional chemical transport model (GEOS-Chem). Our focus on the seasonal variability of emissions was framed in order to refine our understanding of the microbial source of $\mathrm{NO}_{\mathrm{x}}$ over China. McElroy and Wang [2005] proposed that reduction of nitrite by nitrifying bacteria under low oxygen conditions could provide a significant source of $\mathrm{NO}_{\mathrm{x}}$ and suggested that this source had been significantly underestimated in contemporary models of tropospheric chemistry. The temporal coverage of their study, however, was limited to spring [Wang et al., 2004]. The present study extends the analysis to other seasons assessing the validity of their conclusions based on comparison with the satellite observations.

[5] The GOME instrument on the European Remote Sensing-2 (ERS-2) satellite provides information on column densities of $\mathrm{NO}_{2}$ based on analysis of observations of solar radiation backscattered from the nadir over the $423-451 \mathrm{~nm}$ spectral region where $\mathrm{NO}_{2}$ has an important absorption feature [Burrows et al., 1999]. Coverage is available globally every 3 days with a surface footprint of $320 \mathrm{~km}$ by $40 \mathrm{~km}$. The satellite was launched in April 1995 into a Sunsynchronous orbit and provided data globally from August 1995 to June 2003. Compared with higher-resolution measurements of $\mathrm{NO}_{2}$ columns provided for example by the
Scanning Imaging Absorption spectrometer for Atmospheric Chartography instrument (SCIAMACHY), observations from GOME allow better temporal coverage (compensated by coarser footprints) and may be more suitable consequently for a study of seasonal variations of emissions. To obtain tropospheric $\mathrm{NO}_{2}$ columns from GOME, several independent retrieval schemes have been developed. Three of those retrievals by researchers at Bremen University [Richter and Burrows, 2002], Dalhousie University/SAO [Martin et al., 2002b], and BIRA/KNMI [Boersma et al., 2004] have been compared by van Noije et al. [2006]. The present investigation uses GOME $\mathrm{NO}_{2}$ retrieved using the Dalhousie/SAO scheme for a 3-year period (1997, 1998, and 2000) and will be applied to develop a seasonal climatology of $\mathrm{NO}_{\mathrm{x}}$ emissions for east China. We omitted data for 1999 since meteorological fields to drive the GEOS-Chem model were not available for that year when this study was conducted.

[6] Observations of $\mathrm{NO}_{2}$ from GOME were used in previous investigations to study tropospheric composition on global and regional scales. Richter et al. [2005] found evidence for significant trends in tropospheric $\mathrm{NO}_{2}$ columns over a number of industrial regions over the period of 1996-2002 and attributed these trends to variations in local emissions. In contrast to the decreasing trend in column $\mathrm{NO}_{2}$ inferred for northeastern US and Western Europe, they found evidence for a large increasing trend of up to about $10 \% /$ year in early $2000 \mathrm{~s}$ over eastern China. Irie et al. [2005] evaluated GOME $\mathrm{NO}_{2}$ columns retrieved by the Bremen group for this period by comparing them to observations of total $\mathrm{NO}_{2}$ obtained using ground-based $\mathrm{UV} /$ visible spectrometers at sunrise or sunset at three clean sites peripheral of East Asia. Their data were corrected using coincident observations from satellite solar occultation sensors to allow for the contribution to observed column densities due to $\mathrm{NO}_{2}$ in the stratosphere. They concluded that tropospheric $\mathrm{NO}_{2}$ columns inferred from GOME were in good agreement with the ground-based observations within stated error ranges for both, lending support to the results of Richter et al. [2005]. They recognized, however, that ground-based UV/visible spectrometer observations of daytime conditions in polluted regions were needed for precise validation of the GOME analysis for East Asia. van der A et al. [2006] analyzed the trend and seasonal variability of tropospheric $\mathrm{NO}_{2}$ columns over China derived from GOME and SCIAMACHY over a 9-year period (1996-2004). Their study also suggested large increases in the concentration of tropospheric $\mathrm{NO}_{2}$ over eastern China, especially above industrial areas distinguished by rapid economic growth. Different seasonal cycles were identified in their study for the east and west parts of China and were attributed to differences in emissions.

[7] GOME $\mathrm{NO}_{2}$ observations were employed in a number of studies to constrain estimates of $\mathrm{NO}_{\mathrm{x}}$ emissions. Martin et al. [2003a] developed a top-down emission inventory for $\mathrm{NO}_{\mathrm{x}}$ using the GOME data for 1997 exploiting the local GEOS-Chem model relationship between $\mathrm{NO}_{2}$ columns and $\mathrm{NO}_{\mathrm{x}}$ emissions. The resulting $\mathrm{NO}_{\mathrm{x}}$ emissions inferred for the US were about $10 \%$ higher than those included in the a priori inventory employed by GEOS-Chem. They attributed the differences to an underestimate of emissions of $\mathrm{NO}_{\mathrm{x}}$ 
from soils in the a priori formulation. Their study did not, however, find evidence for significant differences between a priori and top-down emissions for East Asia. They reported evidence for significant seasonal variations in differences between a priori and a posteriori emissions of $\mathrm{NO}_{\mathrm{x}}$ over East Asia (from non-biomass-burning regions): a posteriori emissions were higher than a priori in winter and lower in summer. Differences over East Asia canceled out over the course of a year and the a posteriori annual emissions appeared to be in good agreement with annual average a priori emissions adopted by Martin et al. [2003a]. Major improvements to the GEOS-Chem model following the work of Martin et al. [2003a] include the development of an online aerosol simulation as described below, and the use of different reaction probabilities $(\gamma)$ defined by more recent laboratory studies to describe hydrolysis of $\mathrm{N}_{2} \mathrm{O}_{5}$ on different types of aerosols, a major sink for atmospheric $\mathrm{NO}_{\mathrm{x}}$ especially in the winter [Evans and Jacob, 2005]. We shall show that the procedure adopted to account for cloud screening and background levels of $\mathrm{NO}_{2}$ columns could introduce significant biases in the seasonality of emissions derived from GOME. Jaeglé et al. [2005] developed the methodology of Martin et al. [2003a] to identify particular source types and inferred a significant soil source for $\mathrm{NO}_{\mathrm{x}}$ at northern midlatitudes, larger than a priori estimates by a factor of 2. Ma et al. [2006] compared $\mathrm{NO}_{2}$ columns inferred from GOME over China with model results using three different bottom-up inventories for $\mathrm{NO}_{\mathrm{x}}$. They found that for all these emission inventories the model underestimated the GOME observations for China with a negative bias ranging from $31 \%$ to $67 \%$. Van Noije et al. [2006], comparing $\mathrm{NO}_{2}$ columns inferred from GOME using different retrieval schemes with a number of model studies, concluded that model results were systematically lower than GOME observations over east China in winter.

[8] We begin by describing the atmospheric chemistry transport model and the bottom-up inventory for $\mathrm{NO}_{\mathrm{x}}$ used in our analysis (section 2). The retrieval of tropospheric $\mathrm{NO}_{2}$ columns from GOME is presented in section 3 and is used in section 4 to derive top-down constraints on seasonal variations of $\mathrm{NO}_{\mathrm{x}}$ sources over east China. Section 4 discusses the resulting optimized representation of emissions evaluating its accuracy by comparing model results with available surface measurements. Section 5 exploits the discrepancies in seasonality between the top-down and bottom-up inventories for east China and partitions the optimized inventory of $\mathrm{NO}_{\mathrm{x}}$ derived from GOME among biomass burning, fuel combustion and microbial sources. Summary remarks are presented in section 6 .

\section{Atmospheric Chemical Transport Model and Bottom-Up Inventory}

[9] The GEOS-Chem global 3-D model of atmospheric chemistry is used in the present study to simulate abundances of tropospheric $\mathrm{O}_{3}-\mathrm{NO}_{\mathrm{x}}$-hydrocarbon-aerosol for 1997 , 1998, and 2000. The model is driven by meteorological data assimilated by the Goddard Earth Observing System (GEOS) at the NASA Global Modeling and Assimilation Office (GMAO). The meteorological data include 3-D fields updated every 3 hours for surface fluxes and mixing depths, and every 6 hours for other variables. We use version 7-01-02 of GEOS-Chem (http://www-as.harvard.edu/chemistry/trop/ geos) with a horizontal resolution of $2^{\circ}$ latitude by $2.5^{\circ}$ longitude with 30 vertical sigma levels, extending from the surface to $0.01 \mathrm{hPa}$. The lowest $2 \mathrm{~km}$ is resolved using nine layers with midpoints at 10, 45, 115, 220, 370, 580, 870, 1250 , and $1740 \mathrm{~m}$ altitude for a column based at sea level.

[10] The tropospheric $\mathrm{O}_{3}-\mathrm{NO}_{\mathrm{x}}$-hydrocarbon simulation in GEOS-Chem was described first by Bey et al. [2001] with updates by Fiore et al. [2002] and Martin et al. [2002a]. The aerosol simulation in the current version of the model includes treatments of $\mathrm{H}_{2} \mathrm{SO}_{4}-\mathrm{HNO}_{3}-\mathrm{NH}_{3}$ aerosol thermodynamics [Park et al., 2004], organic and elemental carbon [Park et al., 2003], sea-salt [Alexander et al., 2005], and dust [Fairlie et al., 2007]. The model allows for natural sources of sulfur from sea salt and from oxidation of DMS [Park et al., 2004; Alexander et al., 2005]. The aerosol and oxidant chemistry are coupled through the formation of sulfate and nitrate, heterogeneous chemistry, and aerosol effects on photolysis rates. Optical properties are calculated for each aerosol component as a function of local relative humidity as described by Martin et al. [2003b]. Reactions involving aerosols are described by Jacob [2000] with updates for $\mathrm{N}_{2} \mathrm{O}_{5}$ hydrolysis as developed by Evans and $\mathrm{Jacob}$ [2005]. Photolysis frequencies are computed using the Fast-J radiative transfer algorithm [Wild et al., 2000] which allows for Rayleigh scattering as well as for Mie scattering by clouds and aerosols. Simulation of wet and dry deposition follows the schemes developed by Bey et al. [2001]. Extension to moderately soluble gases with low retention efficiencies upon cloud freezing was treated as described by Park et al. [2004].

[11] Table 1 summarizes the seasonal variation of $\mathrm{NO}_{\mathrm{x}}$ emissions from east China $\left(100-123^{\circ} \mathrm{E}\right.$ and $\left.20-42^{\circ} \mathrm{N}\right)$ assumed for all sources in the GEOS-Chem model. Emissions from east China account for about $85 \%$ of the Chinese national total for combustion sources, $60 \%$ for microbial sources. Anthropogenic $\mathrm{NO}_{\mathrm{x}}$ emissions were taken from the Global Emission Inventory Activity (GEIA) [Benkovitz et al., 1996], scaled by country on the basis of energy statistics for 1998 (the last year for which statistics were available) as described by Bey et al. [2001]. Time-of-day and day-of-theweek variations were based on Environmental Protection Agency [1989] as described by Jacob et al. [1993]. No seasonal variation was applied in the model for $\mathrm{NO}_{\mathrm{x}}$ emissions from fossil fuel and biofuel over China (i.e., emissions are assumed to be constant with season). The inventory of emissions from biomass burning allows for seasonal and interannual variations based on satellite observations of fires from the Along Track Scanning Radiometer (ATSR) and aerosols from the Total Ozone Monitoring Spectrometer (TOMS) as derived by Duncan et al. [2003]. The combustion component of $\mathrm{NO}_{\mathrm{x}}$ emissions in GEOS-Chem is compared in Table 1 with a recent bottomup inventory developed for China by Streets et al. [2003] for the year 2000. Spatial distributions of the two inventories are quite consistent $\left(\mathrm{r}^{2}=0.80\right)$ while estimates for annual combustion sources over China differ by only $10 \%$. Soil $\mathrm{NO}_{\mathrm{x}}$ emissions are computed in GEOS-Chem using a modified version of the algorithm proposed by Yienger and Levy [1995] with the canopy reduction factors described by Wang et al. [1998]. Emissions of $\mathrm{NO}_{\mathrm{x}}$ from lightning were linked to deep convection following the parameterization of 
Table 1. A Priori $\mathrm{NO}_{\mathrm{x}}$ Emissions for East China $\left(100-123^{\circ} \mathrm{E}, 20-42^{\circ} \mathrm{N}\right)$ Adopted in the GEOS-Chem Model in Comparison With the Bottom-Up Inventory of Streets et al. [2003] ${ }^{\mathrm{a}}$

\begin{tabular}{|c|c|c|c|c|c|c|}
\hline \multirow[b]{2}{*}{ Source } & \multicolumn{5}{|c|}{ A Priori GEOS-Chem Emissions, ${ }^{\mathrm{b}}$ TgN } & \multirow{2}{*}{$\begin{array}{c}\text { Annual Emissions From } \\
\text { Streets et al. }[2003],{ }^{\mathrm{c}} \mathrm{TgN} \\
\end{array}$} \\
\hline & Winter (DJF) & Spring (MAM) & Summer (JJA) & Fall (SON) & Annual Total & \\
\hline Fossil fuel & 0.70 & 0.70 & 0.70 & 0.70 & 2.81 & \\
\hline Biofuels & 0.11 & 0.11 & 0.11 & 0.11 & 0.43 & 2.86 \\
\hline Biomass burning & 0.004 & 0.014 & 0.010 & 0.017 & 0.044 & 0.11 \\
\hline Microbial sources & 0.016 & 0.060 & 0.120 & 0.040 & 0.236 & N/A \\
\hline Lightning & 0.000 & 0.020 & 0.111 & 0.017 & 0.148 & N/A \\
\hline Aircraft & 0.004 & 0.003 & 0.005 & 0.006 & 0.018 & N/A \\
\hline \multirow[t]{2}{*}{ Total } & 0.83 & 0.91 & 1.05 & 0.89 & 3.68 & 2.97 \\
\hline & \multicolumn{5}{|c|}{ A Posteriori Emissions With Uncertainty, ${ }^{\mathrm{d}} \mathrm{TgN}$} & \multirow{2}{*}{$\begin{array}{l}\text { Annual Change Relative to } \\
\text { the a Priori }\end{array}$} \\
\hline Source & Winter (DJF) & Spring (MAM) & Summer (JJA) & Fall $(\mathrm{SON})$ & Annual Total & \\
\hline Combustion source (fossil fuel + biofuel) & $1.17 \pm 0.37$ & $0.86 \pm 0.27$ & $0.83 \pm 0.27$ & $0.86 \pm 0.27$ & $3.72 \pm 1.2$ & $+15 \%$ \\
\hline Microbial source & $0.04 \pm 0.016$ & $0.21 \pm 0.08$ & $0.36 \pm 0.14$ & $0.24 \pm 0.10$ & $0.85 \pm 0.34$ & $+260 \%$ \\
\hline Biomass burning & $0.008 \pm 0.004$ & $0.03 \pm 0.015$ & $0.02 \pm 0.01$ & $0.03 \pm 0.015$ & $0.08 \pm 0.04$ & $+100 \%$ \\
\hline Total & $1.22 \pm 0.37$ & $1.10 \pm 0.33$ & $1.21 \pm 0.36$ & $1.13 \pm 0.34$ & $4.66 \pm 1.40$ & $+33 \%$ \\
\hline
\end{tabular}

${ }^{\mathrm{a}} \mathrm{A}$ posteriori emissions derived in this work are summarized for comparison.

${ }^{\mathrm{b}} \mathrm{A}$ priori emissions are for 1998 .

${ }^{c}$ Emissions reported by Streets et al. [2003] are for 2000.

${ }^{\mathrm{d}}$ A posteriori emissions refer to averages of the 3-year period (1997, 1998, and 2000).

Price and Rind [1992] with vertical profiles taken from Pickering et al. [1998].

[12] The model was spun-up for a 12-month period beginning 1 January 1996. Results for 1997, 1998, and 2000 are used in the present analysis. No interannual variations were applied to fossil and biofuel sources of $\mathrm{NO}_{\mathrm{x}}$. While the strength of biomass burning varies from year to year and was treated on the basis of space-based observations of fire counts and aerosol indices, the magnitude of related sources for China is too small compared with the contribution from combustion to introduce any significant interannual variation in model results. Soil and lightning sources are linked to a number of meteorological parameters of the model (e.g., precipitation rate for soil emissions and cloud top height for lightning) and differ from year to year globally by up to $10 \%$ and $30 \%$ respectively. These sources, however, exhibit much smaller interannual variations over China than those inferred for the globe as a whole.

\section{GOME Tropospheric $\mathrm{NO}_{2}$ Columns}

\subsection{General Retrieval}

[13] Our retrieval of tropospheric $\mathrm{NO}_{2}$ columns from GOME is based on the algorithm of Martin et al. [2002a, 2003b]. The validity of their algorithm was established using analyses of GOME data for the US [Martin et al. 2002b] and evaluated further using aircraft observations over eastern Texas and the southeastern US [Martin et al., 2004]. Slant column densities of $\mathrm{NO}_{2}$ for the 3 -year period were obtained by fitting backscattered radiance spectra over the 423-451 nm spectral region [Chance et al., 2000; Martin et al., 2002b], using a fixed solar reference spectrum to minimize the diffuser plate artifact [Richter and Wagner 2001; Martin et al., 2002b]. After removal of contributions from stratospheric $\mathrm{NO}_{2}$ and instrument biases, slant column measurements were converted to tropospheric $\mathrm{NO}_{2}$ columns through the application of air mass factors (AMFs). The $\mathrm{AMF}$ is the ratio of the slant to the vertical column and is calculated with a radiative transfer model [Spurr et al., 2001; Spurr, 2002] as a function of the viewing geometry, the scattering properties of the atmosphere and the surface, and the relative vertical distribution of $\mathrm{NO}_{2}$ (shape factor) [Palmer et al., 2001]. The shape factor is specified for each GOME scene using the GEOS-Chem simulation of the scene sampled at the time of the satellite overpass. The AMF formulation used here corrects for the presence of aerosols [Martin et al., 2003a] and for retrieval in the presence of clouds [Martin et al., 2002b]. For easy comparison with the GEOS-Chem model, monthly averaged $\mathrm{NO}_{2}$ columns retrieved from GOME were regridded onto a $2^{\circ}$ latitude by $2.5^{\circ}$ longitude grid and compared with monthly mean model results sampled at the time of the satellite overpass. Monthly mean uncertainties in the tropospheric vertical column retrieved from GOME, after accounting for random errors in each GOME scene and averaging onto a $2^{\circ} \times 2.5^{\circ}$ grid box, include an absolute uncertainty of $5 \times 10^{14}$ molecules $/ \mathrm{cm}^{2}$ introduced as a result of the spectral fitting and subtraction of the stratospheric $\mathrm{NO}_{2}$ columns and a $30 \%$ relative error attributed to uncertainties in the AMF calculation. A detailed error analysis is provided by Martin et al. [2002b] and Boersma et al. [2004].

\subsection{Stratospheric Columns}

[14] Stratospheric slant columns were determined on a daily basis as a function of both latitude and longitude. The zonal invariance assumption for stratospheric $\mathrm{NO}_{2}$ introduced by Martin et al. [2002b] is not expected to introduce significant error under summer conditions for low latitudes [Martin et al., 2002b]. It is questionable, however, north of $30^{\circ} \mathrm{N}$ in other seasons as a result of the expected dynamical variability of the stratosphere [Boersma et al., 2004]. We adopted the zonal variability of stratospheric $\mathrm{NO}_{2}$ derived from the assimilation of the GOME data by Boersma et al. [2004]. We scaled the assimilated stratospheric $\mathrm{NO}_{2}$ columns on a daily basis to match our retrieval over the reference region (the remote central Pacific as defined in 
(a) zonal variation of stratospheric NO2 DJF

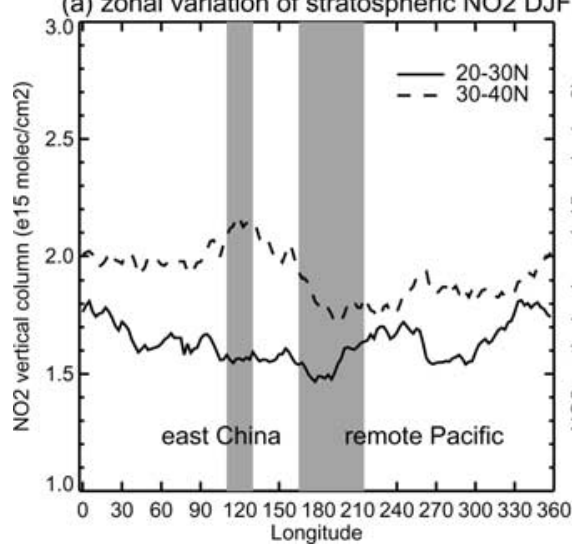

(b) zonal variation of stratospheric NO2 JJA

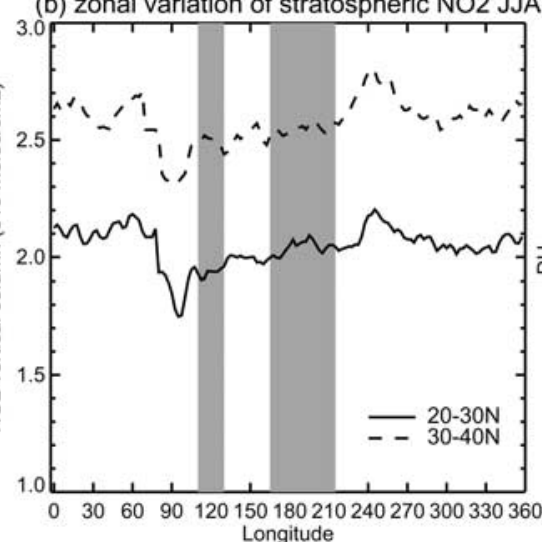

(c) zonal variation of TOMS total ozone DJF

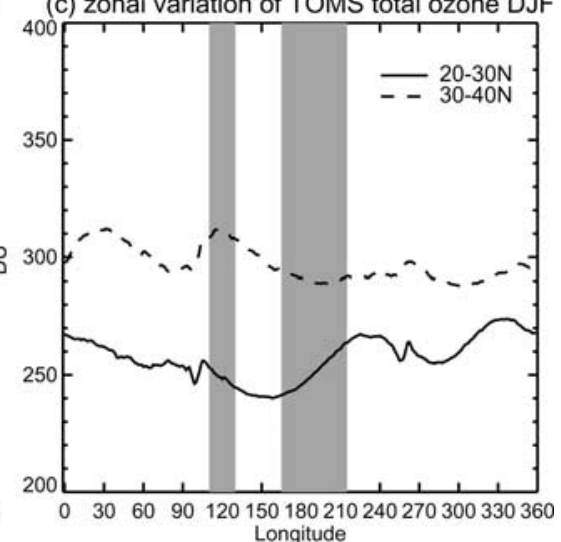

Figure 1. Variations of stratospheric $\mathrm{NO}_{2}$ columns with longitude for (a) winter and (b) summer adopted from the assimilated GOME observations [Boersma et al., 2004]. Data shown are stratospheric vertical column densities of $\mathrm{NO}_{2}$ (unit is $10^{15}$ molecules $/ \mathrm{cm}^{2}$ ) averaged over two latitudinal bands: 20 $30^{\circ} \mathrm{N}$ (solid lines) and $30-40^{\circ} \mathrm{N}$ (dashed lines) for the 3-year period $(1997,1998$, and 2000). The two shaded areas indicate the approximate longitudinal extent of east China and the remote Pacific region. (c) Same as Figure 1a but for total column densities of ozone (Dobson Unit) inferred from the TOMS instrument.

Martin et al. [2002b]), accounting only for the zonal variations of the assimilated data. The zonal variability of stratospheric slant columns adopted from the assimilated data set for two latitudinal bands $\left(20-30^{\circ} \mathrm{N}\right.$ and $\left.30-40^{\circ} \mathrm{N}\right)$ for winter (December-January-February; DJF) and summer (June-July-August; JJA) are displayed in Figures 1a and 1b. The data shown here reflect averages for the 3-year period $(1997,1998$, and 2000). It is evident from Figures 1a and $1 b$ that the variation of stratospheric columns of $\mathrm{NO}_{2}$ with longitude is significant at higher latitudes in winter. Column densities of total ozone inferred from the TOMS instrument (http://toms.gsfc.nasa.gov/ozone/ozoneother.html) exhibit a similar pattern of zonal variance in winter (Figure 1c). The zonal asymmetry of $\mathrm{O}_{3}$ and $\mathrm{NO}_{2}$ in the extratropical stratosphere in winter reflects transport by planetary scale waves originating in the troposphere as a response to topography and land-ocean heating contrasts. The variation of stratospheric $\mathrm{NO}_{2}$ with longitude averages about $5 \times$ $10^{14}$ molecules $/ \mathrm{cm}^{2}$ globally, less than the uncertainty of $1 \times 10^{15}$ molecules $/ \mathrm{cm}^{2}$ attributed to spectral fitting of individual GOME scenes [Martin et al., 2002b]. A neglect of zonal variations in the contribution of stratospheric $\mathrm{NO}_{2}$ would be expected to introduce biases in our subsequent analysis of seasonal variations of tropospheric $\mathrm{NO}_{2}$ over east China. While stratospheric columns averaged over east China between $30-40^{\circ} \mathrm{N}$ are close to those over the remote Pacific in summer, they are higher by about $20 \%$ (or by about $6 \times 10^{14}$ molecules $/ \mathrm{cm}^{2}$ ) in winter. Tropospheric concentrations are adjusted accordingly.

\subsection{Sensitivity to Cloud Screening}

[15] Cloud fraction, cloud top, and cloud optical depths are retrieved for each GOME scene by the GOME Cloud Algorithm (GOMECAT) [Kurosu et al., 1999]. Errors in the treatment of clouds are responsible for a significant source of the uncertainty in the related calculation of AMFs, estimated at $15-30 \%$ if assumed to be random [Martin et al., 2002b; Boersma et al., 2004]. Systematic bias in the
AMF calculation introduced by cloudy conditions, though difficult to quantify, could potentially confound the analysis of seasonal variations since the distribution of clouds over east China exhibits important seasonal variations associated with the East Asia monsoon. Absent suitable in situ observations for east China, we adopt an empirical method described below to estimate the systematic bias involved in the AMF calculation for cloudy conditions by comparing tropospheric vertical columns (TVCs) of $\mathrm{NO}_{2}$ derived from GOME on the basis of different cloud screening thresholds. We choose to use cloud radiance fractions (i.e., the fraction of the radiation backscattered from the cloud covered fraction of the scene [Martin et al., 2002b]) rather than cloud area fractions as a criterion for cloud screening, as the former accounts for the influence of cloud optical depth on observations.

[16] We excluded scenes with cloud radiance fractions greater than $40 \%$ in order to reduce retrieval errors. This threshold eliminates data from scenes defined by the presence of clouds or snow covering more than $20 \%$ of the scene by area. Despite this exclusion, the remaining data still allow excellent spatial coverage over east China for individual months. TVCs derived using this threshold are referred to in the later discussion as TVCs with $40 \%$ cloud screening. Another set of TVCs were derived using a $20 \%$ cloud screening criterion. After regridding to a common model resolution $\left(2^{\circ}\right.$ latitude by $2.5^{\circ}$ longitude), monthly mean TVCs retrieved on the basis of $20 \%$ cloud screening are compared on a grid-by-grid basis with those obtained using the $40 \%$ threshold. Results of this comparison are summarized in Figure 2, which presents 3-year averages of monthly mean TVCs for two subregions of east China: north China $\left(100-123^{\circ} \mathrm{E}, 30-42^{\circ} \mathrm{N}\right.$ (Figure 2, left)) and south China $\left(100-123^{\circ} \mathrm{E}, 20-30^{\circ} \mathrm{N}\right.$ (Figure 2, right)). As illustrated in Figure 2, differences in TVCs obtained using different cloud thresholds can amount to as much as $20 \%$ for some months and differences vary both seasonally and regionally. For north China, TVCs obtained using the $20 \%$ 

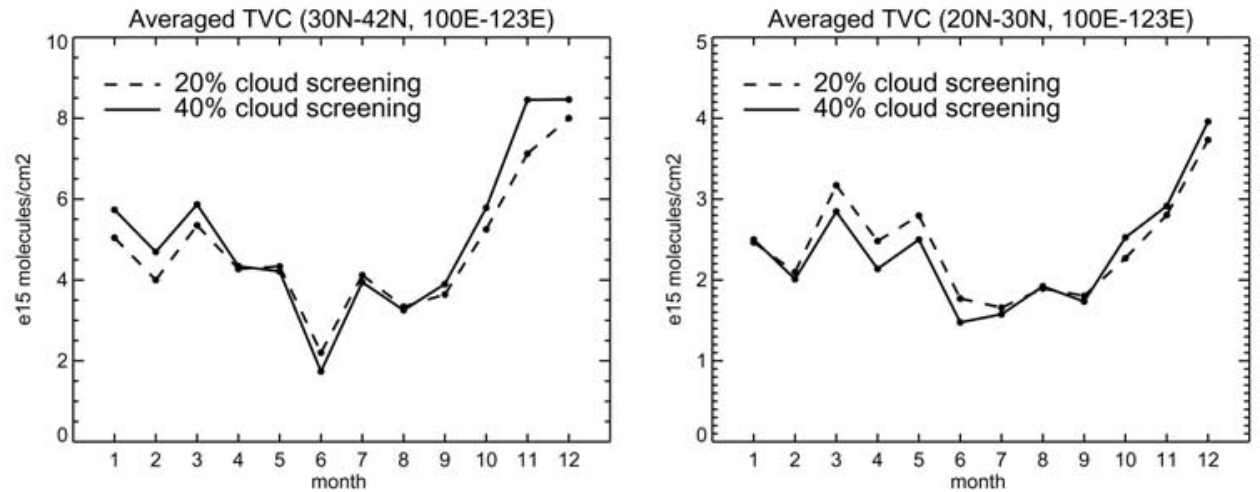

Figure 2. Tropospheric vertical columns (TVCs) of $\mathrm{NO}_{2}$ retrieved from GOME with the $40 \%$ cloud screening threshold (solid line) and 20\% cloud threshold (dashed line) averaged for two subregions of east China: (left) north China $\left(30-40^{\circ} \mathrm{N}, 100-123^{\circ} \mathrm{E}\right)$ and (right) south China $\left(20-30^{\circ} \mathrm{N}, 100-123^{\circ} \mathrm{E}\right)$. Data shown are 3-year averages of monthly mean TVCs sampled at the same grids for the two cloud screening.

cloud threshold are about 20\% lower in winter and fall while slightly higher in summer as compared to results obtained using the $40 \%$ threshold. For south China, column densities obtained using the $20 \%$ criterion are higher by about $20 \%$ in spring and summer than those derived using the $40 \%$ threshold. Differences are insignificant in winter.

[17] There are three possible explanations for the differences displayed in Figure 2. The difference in winter in the north is related most likely to the fact that an important part of the landscape may be snow covered for this time of year. The surface reflectivity fields used in the present study were derived on the basis of the minimum Lambert-equivalent reflectivity values inferred for the surface from analyses of GOME data over the course of a month [Koelemeijer et al., 2003]. Consequently they fail to account for day-to-day variations in snow cover. This may be expected to lead to an overestimate of the column density of $\mathrm{NO}_{2}$ for scenes defined by significant day-to-day variations in snow cover. The GOMECAT cloud algorithm, however, interprets daily varying snow cover as clouds. Use of the $20 \%$ cloud exclusion threshold ensures that a larger fraction of scenes with temporary snow cover are eliminated as compared to results obtained using the $40 \%$ cloud threshold. As a result, TVCs inferred using the $20 \%$ cloud exclusion threshold tend to be lower than those derived using the $40 \%$ threshold for winter in the north. In the absence of snow, the difference in winter is unimportant for the south. Second, sampling bias could contribute to the differences. The comparison presented in Figure 2 is based on monthly mean TVCs obtained using different cloud exclusion thresholds for individual GOME scenes. Compared with the scenes selected using the $40 \%$ cloud exclusion threshold for a given resolution element for a given month, only a subset of scenes are used when the $20 \%$ threshold is adopted. This difference in sampling could introduce bias in results to the extent that column densities of $\mathrm{NO}_{2}$ may be expected to vary in response to variations in local cloud cover. It is difficult to quantify the importance of this correlation. We attempted to estimate it using the GEOSChem model simulation. We sampled model TVCs following the strategy adopted for analyses of the GOME data with $20 \%$ and $40 \%$ cloud screening and found that model TVCs were insensitive to this choice of selection. We concluded therefore that either the sampling bias should not introduce important errors, or that the GEOS-Chem model might underestimate the importance of the coupling between clouds and $\mathrm{NO}_{2}$ columns. Third, it is possible also that biases may be built into the cloud retrieval algorithm (e.g., cloud properties), the radiative transfer calculation for cloudy conditions, and the vertical profile of $\mathrm{NO}_{2}$ below clouds provided by the GEOS-Chem model. Using scenes with smaller cloud fraction is expected to reduce the uncertainties in the AMF related to most of these parameters [Martin et al., 2002b]. Higher TVCs with lower cloud screening in spring and summer (seasons with high cloud cover) over south China is consistent with the positive bias of $17 \%$ in AMFs for cloudy conditions reported by Millet et al. [2006] in their analysis of GOME formaldehyde observations.

[18] To reduce retrieval errors and biases introduced by the presence of clouds, monthly mean TVCs were constructed using GOME scenes defined by cloud radiance fractions of less than $20 \%$. With this screening, about one third of grid cells over east China were excluded for any given month reflecting persistent extensive cloud cover and the region excluded can vary significantly from month to month. To remove biases introduced by incomplete spatial sampling, data gaps were filled with TVCs using higher cloud thresholds, first $30 \%$ and then $40 \%$. After the data gaps were filled with results obtained up to the $40 \%$ cloud threshold, spatial coverage of more than $95 \%$ was obtained for most months for east China. This cloud screening approach is intended to minimize retrieval biases associated with clouds and snow cover and will be referred in what follows as a bias-reducing cloud screening, an approach differing from that used in prior studies in which a uniform cloud fraction criterion was selected for cloud screening [Martin et al., 2002b; Richter et al., 2005]. Differences in monthly mean TVCs over east China between our biasreducing cloud screening approach and a uniform $40 \%$ screening are typically within $\pm 10 \%$, changing sign for different seasons (see Figure 2). As a consequence, differ- 


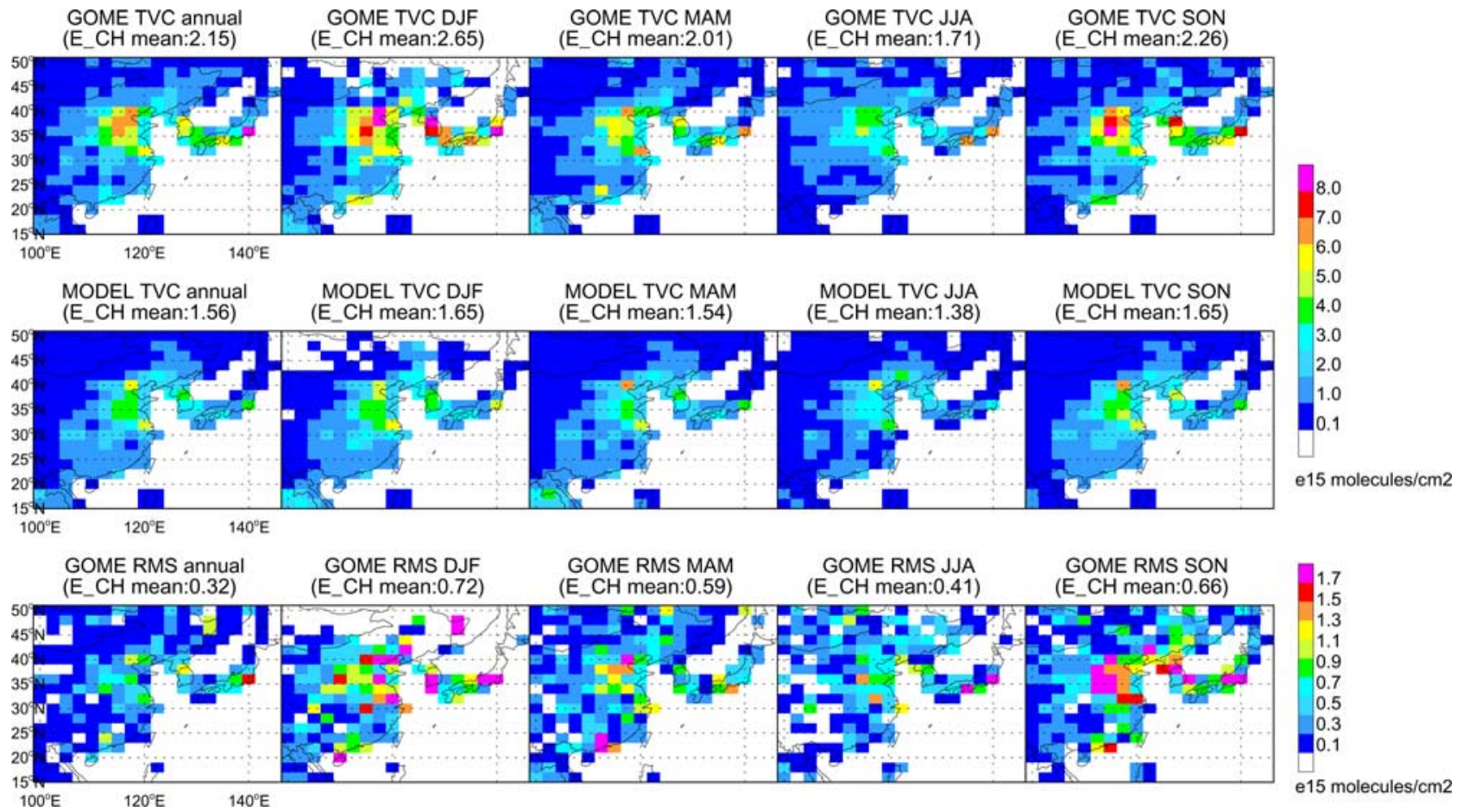

Figure 3. Average annual and seasonal distributions of tropospheric $\mathrm{NO}_{2}$ columns derived from (top) GOME and (middle) the GEOS-Chem model using a priori emissions. The four seasons are defined as follows: winter (December-January-February; DJF), spring (March-April-May; MAM), summer (JuneJuly-August; JJA), and fall (September-October-November; SON). (bottom) RMS differences associated with the GOME columns. Note that the bottom plots have different color scales than the top and middle plots. The numbers listed on top of each figure (unit is $10^{15}$ molecules $/ \mathrm{cm}^{2}$ ) refer to column densities of $\mathrm{NO}_{2}$ averaged for east China.

ences when averaged over the course of a year are typically less than $10 \%$. The bias-reducing cloud screening approach is expected to provide a more reliable record of seasonal variability.

\subsection{GOME $\mathrm{NO}_{2}$ Columns and Comparison With Model}

[19] Average annual and seasonal distributions of TVCs over east China retrieved from GOME using the biasreducing cloud screening are presented in Figure 3 (top). The data refer to averages for the 3-year period (1997, 1998, and 2000). We used scene-specific AMFs for each observation, accounting for seasonal and interannual variations in AMFs. We found no evidence over this period for the large secular trend in TVCs reported by Richter et al. [2005] from their temporally more extensive (1996-2004) analysis of GOME data over east China. As a consequence, monthly variations of GOME TVCs were estimated using linear averages of the 3-year data and were averaged further to develop seasonal and annual fields. Since GOME data are unavailable for January 1998, we used data for January 1997 as a substitute to avoid biases in annual and seasonal averages introduced by month to month variations in $\mathrm{NO}_{2}$. Averaging multiyear data allows for spatially complete satellite sampling over east China and provides a satisfactory representation of mean climatological conditions. Corresponding TVCs from GEOS-Chem sampled on the overpass time of GOME and averaged using the same approach as in the treatment of the GOME data are displayed in Figure 3 (middle). The model captures approximately $80 \%$ of the spatial variance in vertical columns inferred from GOME over east China for all seasons, but systematically underestimates observed TVCs. Annual mean TVCs derived using the model for east China are lower than the GOME-derived columns by about $40 \%$. The underestimate appears to be larger in winter than in summer and greater in the north than in the south. A number of sensitivity tests were carried out to verify that the discrepancies between GOME and model TVCs could be attributed mostly to deficiencies in a priori emissions. In one test, we doubled the optical thickness of scattering aerosols (sulfate and dust) assumed in the retrieval and found an increase of $3 \%$ in AMFs with a corresponding 3\% decrease in GOME TVCs. This small change reflects competing effects on the AMF due to multiple scattering at the top of the aerosol layer, and obscuration of $\mathrm{NO}_{2}$ below. In another test, we decreased the reaction probability $\left(\gamma_{\mathrm{N} 2 \mathrm{O} 5}\right)$ of hydrolysis of $\mathrm{N}_{2} \mathrm{O}_{5}$ on aerosols by $50 \%$ over China in light of the recent work of Brown et al. [2006] and found an increase of only $5 \%$ in model TVCs sampled at the overpass time of GOME in winter. A large discrepancy was found also over Japan where the model underestimates GOME TVCs by about $30 \%$. This discrepancy was indicated in previous studies [Martin et al., 2003a; van Noije et al., 2006; Jaeglé et al., 2005]. Jaeglé et al. [2005] suggested a $25 \%$ increase in combustion emissions of $\mathrm{NO}_{\mathrm{x}}$ over Japan according to 
\% of background TVC DJF $\quad \%$ of background TVC JJA $\quad \%$ of background TVC annual
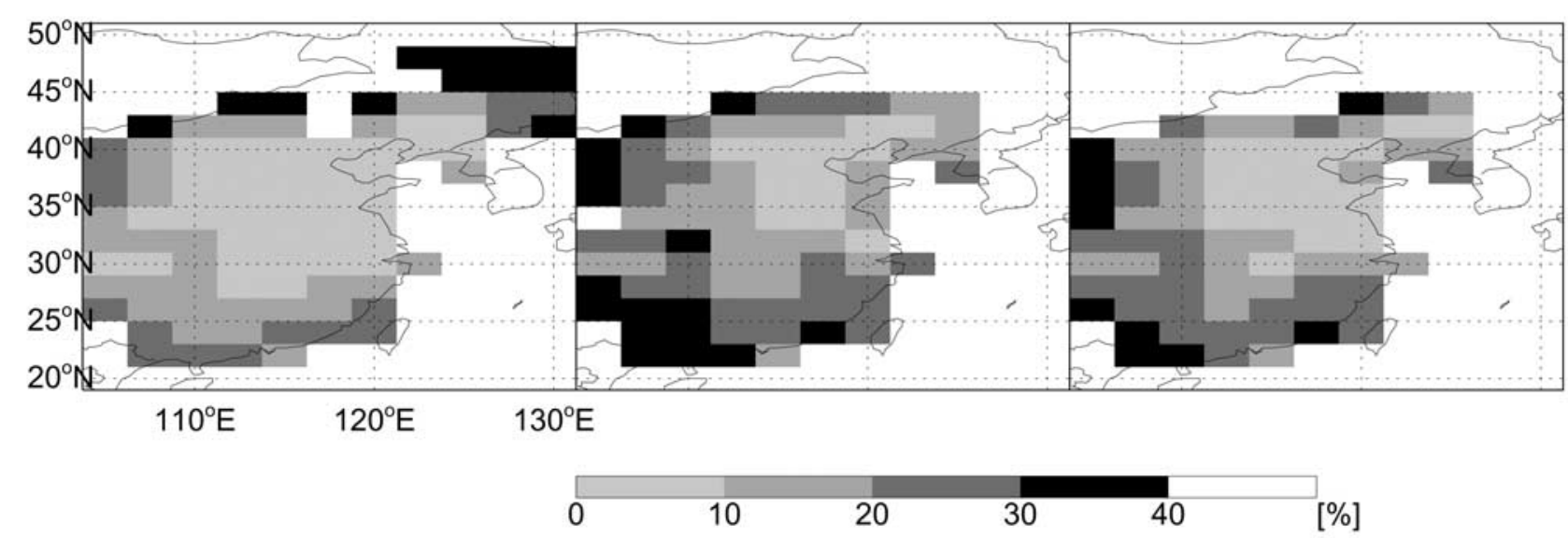

Figure 4. Average percentage ratio of background tropospheric $\mathrm{NO}_{2}$ columns to total $\mathrm{NO}_{2}$ columns at local overpass of GOME. Results are shown for (left) winter (DJF), (middle) summer (JJA), and (right) for all seasons (annual).

their partitioning of GOME-derived emissions, but the factors responsible for the underestimate over Japan remain unresolved.

[20] Interannual variations in the GOME observations are evaluated using the root-mean-square (RMS) differences between the mean fields and the yearly specific fields. The spatial distribution of RMS differences in TVCs derived from GOME is presented in Figure 3 (bottom). For a typical $2^{\circ} \times 2.5^{\circ}$ grid over east China, seasonally averaged RMS accounts for about $30 \%$ of the mean, indicating large interannual variations in the GOME observations on a grid scale attributable to both meteorology and emissions. Large interannual variations in the GOME data could account for the failure of the present study to detect any significant trend in $\mathrm{NO}_{2}$ columns over east China. In the presence of interannual variations of $30 \%$, it would require 8 years of observations to infer a significant annual trend at a level of 5\% [Weatherhead et al., 1998]. Trends in $\mathrm{NO}_{2}$ columns inferred by Richter et al. [2005] for east China were based on grid-scale calculations using 9 years of data.

\section{Seasonal Variability of GOME-Derived Emissions}

\subsection{Background Contributions}

[21] The methodology used to derive optimized $\mathrm{NO}_{\mathbf{x}}$ emission inventories from GOME observations was based on Martin et al. [2003a]. Local $\mathrm{NO}_{\mathrm{x}}$ emissions were inferred using a chemical inversion accounting for the local $\mathrm{NO}_{2} / \mathrm{NO}_{\mathrm{x}}$ ratio and the local $\mathrm{NO}_{\mathrm{x}}$ lifetime. In the chemical inversion scheme used here, we improved on previous work in establishing the relationship between local emissions and tropospheric $\mathrm{NO}_{2}$ columns by accounting for long-range transport of $\mathrm{NO}_{2}$.

[22] Contributions from external and nonsurface sources (such as lightning and aircraft) to tropospheric $\mathrm{NO}_{2}$ columns over east China were identified by sensitivity simulations using GEOS-Chem in which surface emissions from east China were omitted. The importance of "background"
$\mathrm{NO}_{2}$ columns defined through the sensitivity simulation is accessed by examining the ratio of background to total columns over east China at local overpass of GOME. Results averaged for the 3-year period are presented in Figure 4 for winter (Figure 4, left), summer (Figure 4, middle), and for all seasons (Figure 4, right). Background columns contribute about $10 \%$ to the total columns simulated north of $25^{\circ} \mathrm{N}$ in winter, increasing to about $30 \%$ south of $30^{\circ} \mathrm{N}$ in summer. The magnitude of background columns (not shown) is higher in summer than winter and higher in the south than north. Background column densities of $\mathrm{NO}_{2}$ were calculated to average $4 \times 10^{14}$ molecules $/ \mathrm{cm}^{2}$ south of $30^{\circ} \mathrm{N}$, with slightly lower values, $3 \times 10^{14}$ molecules $/ \mathrm{cm}^{2}$, to the north. Despite the fact that the lifetime of $\mathrm{NO}_{\mathrm{x}}$ in the boundary layer is lower in summer than in other seasons, enhanced convective activity and instability of the lower atmosphere contribute in that season to lifting a larger fraction of boundary layer $\mathrm{NO}_{\mathrm{x}}$ into the free troposphere to be transported subsequently over long distances, resulting in a decrease in local column densities compensated by an increase elsewhere. Lightning sources of $\mathrm{NO}_{\mathrm{x}}$, which peak typically in summer, contribute also to an increase in the significance of background $\mathrm{NO}_{2}$. An additional contribution to background $\mathrm{NO}_{2}$ is related to seasonal burning of biomass in Southeast Asia, which accounts for enhanced background columns detected over southern China in spring (not shown). In a sensitivity test in which background columns were assumed to be zero, a posteriori emissions as derived below were found to be reduced in the south by $8 \%$ in spring and summer and by $4 \%$ in other seasons, with insignificant changes in the north. This indicates that background columns exert an important influence mainly in the south.

[23] We assume that the GEOS-Chem model can provide a satisfactory estimate for the contribution of long-range transport to TVCs inferred from GOME over east China. The error associated with the background columns calculated by the model should correspond roughly to the uncertainty in $\mathrm{NO}_{\mathrm{x}}$ emissions inferred for northern midlat- 
itudes. It was shown previously that GOME columns over land were relatively insensitive to NO produced by lightning reflecting the low densities and low $\mathrm{NO}_{2} / \mathrm{NO}$ ratios characteristic of the upper troposphere [Martin et al., 2003a; Jaeglé et al., 2004]. We treat the lightning source of $\mathrm{NO}_{\mathrm{x}}$ as background in the present study and do not attempt to constrain its magnitude. Potential errors in GEOS-Chem with respect to lightning $\mathrm{NO}_{\mathrm{x}}$ [Li et al., 2005; Martin et al., 2006], however, are expected to introduce errors in AMFs (through the shape factor of $\mathrm{NO}_{2}$ ) and in the contribution of background $\mathrm{NO}_{2}$ assumed in GOME observations. Martin et al. [2006] compared $\mathrm{NO}_{2}$ columns retrieved from SCIAMACHY with aircraft observations over North Atlantic in summer and suggested that the lightning source at northern midlatitudes should be increased in GEOS-Chem by a factor of 4 . In a sensitivity test in which $\mathrm{NO}_{\mathrm{x}}$ sources from lightning were increased by a factor of 4 over east China in summer relative to those assumed in GEOS-Chem, we found a $15 \%$ increase in AMFs, with a corresponding 8\% decrease in GOME TVCs and a $15 \%$ reduction in top-down emissions in summer. Although these errors are within the uncertainty range assigned below for top-down emissions, they are nontrivial suggesting the need of better understanding lightning $\mathrm{NO}_{\mathrm{x}}$ over China. It has been suggested further that the microbial source of $\mathrm{NO}_{\mathrm{x}}$ at northern midlatitudes should be increased by a factor of 2 in GEOS-Chem [McElroy and Wang, 2005; Jaeglé et al., 2005], corresponding to about a $30 \%$ increase in total $\mathrm{NO}_{\mathrm{x}}$ sources over the same region. Another sensitivity test was implemented in which the background columns over east China assumed in GOME TVCs were increased by $30 \%$ relative to the GEOS-Chem simulation. This was found to result in a reduction of less than $3 \%$ in the top-down emissions described below. We conclude that the top-down emissions derived from GOME are insensitive to errors in background columns adopted in analysis of the GOME data.

\subsection{Optimized Emissions}

[24] The GEOS-Chem relationship between surface $\mathrm{NO}_{\mathrm{x}}$ emissions and corresponding tropospheric $\mathrm{NO}_{2}$ columns (i.e., total model columns minus background contributions) is derived using a forward simulation based on the a priori inventory. Assuming this relationship to a first approximation independent of emissions [Martin et al., 2003a] which were verified in the present study through sensitivity tests with GEOS-Chem for the range of emissions applicable for China, we infer top-down surface $\mathrm{NO}_{\mathrm{x}}$ emissions over east China using tropospheric $\mathrm{NO}_{2}$ columns inferred from GOME after allowing for contributions from the background. In practice the relationship between $\mathrm{NO}_{2}$ columns and emissions can be determined either locally (i.e., on a grid by grid basis) or regionally. Differences in top-down emissions derived using the grid mapping and regional mapping (we divided east China into segments north and south of $\left.30^{\circ} \mathrm{N}\right)$ were found to be small $(\sim 2 \%)$ on the regional scale and we choose to use the grid mapping in the present study since this approach allows for changes in the spatial pattern of emissions following the GOME data.

[25] The resulting top-down GOME inventory for east China is displayed in Figure 5 (top), and is compared with emissions assumed in the a priori inventory (Figure 5, middle). Figure 5 includes data for individual seasons as well as annual composites. The top-down emissions were derived initially on a monthly basis, accounting for interannual and seasonal variations in the chemical lifetime of $\mathrm{NO}_{\mathrm{x}}$ and transport patterns, and were averaged subsequently to obtain seasonal results. The emissions shown here represent the combined contributions from fossil fuels, biofuels, biomass burning, and microbial sources, excluding nonsurface sources such as lightning and aircraft. The regional total for top-down emissions over east China is $5.13 \mathrm{Tg} \mathrm{N} / \mathrm{yr}, 47 \%$ higher than the estimate of $3.49 \mathrm{Tg} \mathrm{N} / \mathrm{yr}$ included in the a priori inventory. Spatial correlations between the two inventories are high $(\mathrm{r}=0.9, \mathrm{n}=104)$ for all seasons. In contrast to the peak in summer assumed in a priori emissions, the peak in top-down emissions occurs in winter. The increase in annual mean emissions derived from the present analysis is comparable to the increase inferred earlier by Wang et al. [2004] from their inversion analysis of aircraft and station data for the spring of 2001 .

[26] The uncertainty in top-down emissions relates to the retrieval error $\left(5 \times 10^{14}\right.$ molecules $/ \mathrm{cm}^{2}+30 \%$; section 3.1$)$ and further errors associated with linking local $\mathrm{NO}_{2}$ columns to local emissions. The latter error was assessed previously as 30\% [Martin et al., 2003a; Jaeglé et al., 2005]. We tentatively decreased this error to $20 \%$, reflecting what we judge to be an improvement in the procedure adopted here to account for the contribution from background $\mathrm{NO}_{2}$ columns. The overall uncertainty in the topdown inventory over east China is estimated at $38 \%$. The uncertainty in the a priori inventory over east China is taken as a quadratic sum of $27 \%$ for the combustion source [Streets et al., 2003] and 50\% for the microbial source reflecting the underestimate of this source over China inferred from aircraft and surface measurements by Wang et al. [2004]. The top-down inventory is combined then with the a priori inventory, weighted by the relative uncertainty in each, to obtain the a posteriori inventory [Martin et al., 2003a]. The a posteriori emissions are computed on a monthly basis, averaged then to seasonal and annual means as presented in Figure 5 (bottom). The a posteriori inventory over east China is consistent with the a priori emissions in terms of their spatial distribution. It implies however an annual total of $4.66 \mathrm{Tg} \mathrm{N} / \mathrm{yr}, 33 \%$ higher than the a priori result. The uncertainty in the a posteriori inventory is estimated as about $30 \%$ for east China, lower than the uncertainty in either the top-down or in the a priori inventory. Though derived for individual months, this estimate of uncertainty is applied to seasonally and annually mean fields, an approach we view as conservative.

\subsection{Validation of a Posteriori Emissions With Observations}

[27] Only a limited set of in situ measurements are available for different seasons over east China that can be employed to validate the a posteriori emissions derived here. We propose to compare model results with monthly averaged measurements of nitrate wet deposition at two Chinese remote sites from the Acid Deposition Monitoring Network in East Asia (EANET; http://www.eanet.cc/product/ datarep/datarep00/datarep00_wet.pdf) and with measurements of total reactive nitrogen $\left(\mathrm{NO}_{\mathrm{y}}\right)$ from a rural site (Lin An; $30^{\circ} 25^{\prime} \mathrm{N}, 119^{\circ} 44^{\prime} \mathrm{E}$ ) in east China [Wang et al., 2002]. The remote sites included in EANET are located at 


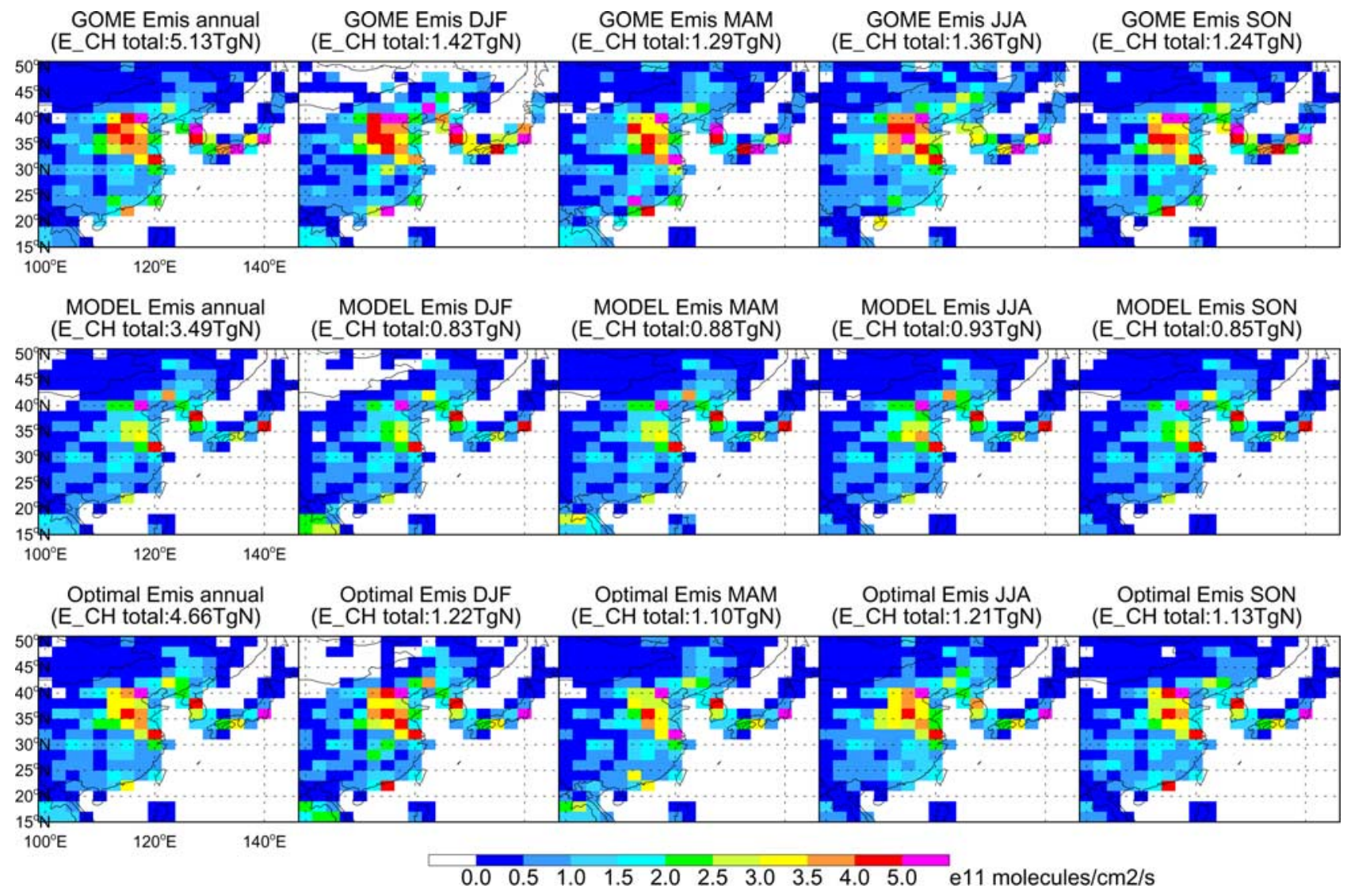

Figure 5. Average annual and seasonal distributions of surface $\mathrm{NO}_{\mathrm{x}}$ emissions in (top) the top-down inventory, (middle) the a priori inventory, and (bottom) the a posteriori inventory. Numbers listed on top of each figure (unit is $\mathrm{Tg} \mathrm{N}$ ) refer to the total regional emissions of $\mathrm{NO}_{\mathrm{x}}$ from east China.

$\mathrm{Xi}$ 'an $\left(33^{\circ} 54^{\prime} \mathrm{N}, 108^{\circ} 51^{\prime} \mathrm{E}\right)$ and Xiamen $\left(24^{\circ} 51^{\prime} \mathrm{N}\right.$, $118^{\circ} 02^{\prime} \mathrm{E}$ ) and provide monthly mean data for 2000 . Precipitation samples were collected using a wet-only sampler on a daily basis at Xiamen and for precipitation events at $\mathrm{Xi}$ 'an. Samples were analyzed for $\mathrm{NO}_{3}^{-}$using ion chromatography. Concentrations of $\mathrm{NO}_{\mathrm{y}}$ at Lin An were measured during a 12-month period (August 1999 to July 2000) with reactive nitrogen species converted to NO using hot molybdenum oxide maintained to $325^{\circ} \mathrm{C}$ with $\mathrm{NO}$ measured subsequently using a chemiluminescence analyzer with a detection limit of $0.05 \mathrm{ppbv}$ [Wang et al., 2002].

[28] Figure 6 presents a comparison of results computed using a posteriori (blue) and a priori (black) emissions with monthly mean observations (red) at the three sites. Figures $6 \mathrm{a}$ and $6 \mathrm{~b}$ present $\mathrm{NO}_{3}^{-}$wet deposition data $\left(\mathrm{nmol} / \mathrm{m}^{2}\right)$ for Xi' an and Xiamen respectively for year 2000. The increase in emissions from east China in the a posteriori case results in a significant increase in wet deposition of $\mathrm{NO}_{3}^{-}$at the two stations, with a much better match of model and observation. Use of the a posteriori emissions leads to an improved simulation also of the seasonal variations observed for deposition of $\mathrm{NO}_{3}^{-}$. The a posteriori model indicates pronounced peaks in $\mathrm{NO}_{3}^{-}$in June and between August and October at Xi'an, similar to patterns reflected in the observations. This behavior is reproduced also by the model with the a prior emission inventory, lending support to the chemistry and deposition schemes in the GEOS-Chem model in simulating seasonal patterns of total reactive nitrogen $\left(\mathrm{NO}_{\mathrm{y}}\right)$ over China. Both model results, however, fail to account for the early peak in April indicated by the observations. At Xiamen, wet deposition of $\mathrm{NO}_{3}^{-}$peaks in April and in summer (JuneAugust), and is attributed to increases in monsoonal rainfall. This feature is captured better with the a posteriori model, although it significantly underestimates the magnitude of $\mathrm{NO}_{3}^{-}$deposition observed in June. Figure 6c displays surface mixing ratios of $\mathrm{NO}_{\mathrm{y}}$ at Lin An. Both models capture the seasonality of $\mathrm{NO}_{\mathrm{y}}$ observations at Lin An, including the maximum observed in winter and the minimum in summer. The negative bias of the model with respect to $\mathrm{NO}_{\mathrm{y}}$ is reduced from $-50 \%$ (or $-60 \mathrm{ppbv}$ ) using the a priori emissions to $-30 \%$ (or $-35 \mathrm{ppbv}$ ) with the a posteriori inventory at Lin An. The a posteriori results are still lower than the observational data at all three sites, reflecting perhaps the deficiency in comparing grid-wide mean quantities with point measurements.

\subsection{Seasonality of Composite Emissions}

[29] The top-down and a posteriori inventories derived using GOME for east China exhibit clear seasonal variations that are not fully captured in the model using the a priori inventory. While total emissions for east China derived from GOME vary only slightly with season (less than $5 \%$ variability is indicated in the a posteriori inventory), distinct spatial variations are apparent and warrant a separate analysis of underlying seasonal variability. Considering 
(a) EANET Xi An site (33.9N, 108.9E)

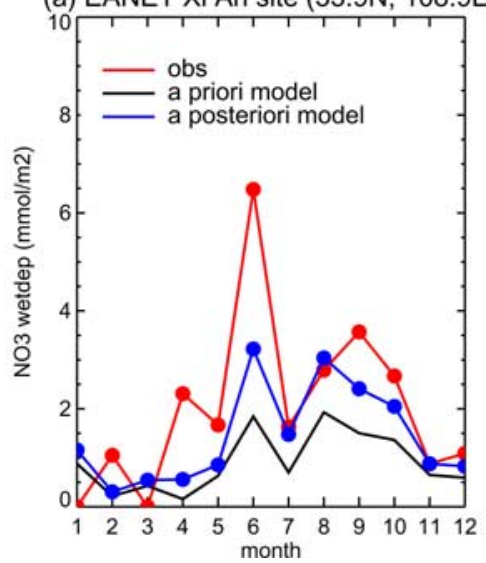

(b) EANET Xiamen site $(24.9 \mathrm{~N}, 118.0 \mathrm{E})$

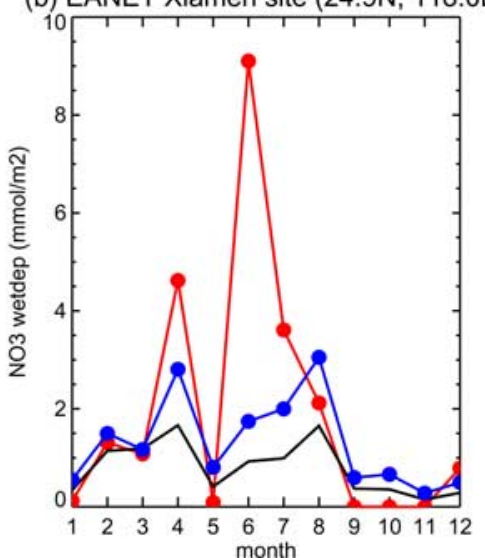

(c) Lin An (32.4N, 119.7E) NOy (1999-2000)

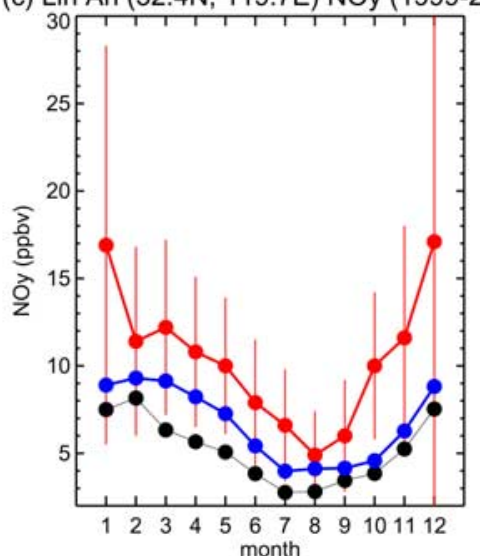

Figure 6. (a) Monthly average nitrate wet deposition at Xi An $\left(33.9^{\circ} \mathrm{N}, 108.9^{\circ} \mathrm{E}\right)$ for 2000 . EANET observations are displayed in red, model results using a priori emissions are displayed in black, and model results using a posteriori emissions are displayed in blue. (b) Same as Figure 6a but for Xiamen $\left(24.9^{\circ} \mathrm{N}, 118.0^{\circ} \mathrm{E}\right)$. (c) Monthly average mixing ratios of $\mathrm{NO}_{\mathrm{y}}$ at $\operatorname{Lin} \mathrm{An}\left(32.4^{\circ} \mathrm{N}, 119.7^{\circ} \mathrm{E}\right)$ between August 1999 and July 2000. Observations are displayed in red (with red vertical lines indicating the standard deviation of observations), model results using a priori emissions are displayed in black, and model results using a posteriori emissions are displayed in blue.

climatic features and traditional divisions in east China, we focus our discussion of seasonal variability on emissions from the following two subregions: temperate north China $\left(100-123^{\circ} \mathrm{E}, 32-40^{\circ} \mathrm{N}\right)$ and subtropical south China $(100-$ $\left.123^{\circ} \mathrm{E}, 18-32^{\circ} \mathrm{N}\right)$. Comparisons of monthly emissions for north and south China averaged over the 3 -year period are presented in Figures $7 \mathrm{a}$ and $7 \mathrm{~b}$, respectively, comparing a priori (black) and top-down inventories (red). RMS differences in the top-down inventory, representing interannual variability of emissions derived from GOME, are indicated by vertical thin lines around monthly means. The estimate of emissions included in the a priori inventory is generally outside \pm RMS of the value derived from the top-down analysis, indicating that it is unlikely that the difference between the two inventories can be attributed to interannual variations in the GOME observations. Nonetheless, interannual variations are often comparable in magnitude to monthto-month differences in the top-down inventory, suggesting a low signal-to-noise ratio in some of the month-to-month variability inferred from the GOME analysis. Interannual variations are especially large for south China. After averaging emissions by season (Figures $7 \mathrm{c}$ and $7 \mathrm{~d}$ ), however, the noise introduced by interannual variations is reduced significantly in the top-down representation. The discussion which follows will focus mainly on seasonally averaged data.

[30] Seasonal variations of surface emissions are presented for north and south China in Figures $7 \mathrm{c}$ and $7 \mathrm{~d}$ respectively. Seasonality in a priori emissions is small and similar for the north and south: the small summer maximum is a direct result of the summer peak in soil emissions. GOME-derived emissions exhibit seasonal variations distinctly different from patterns suggested in the a priori inventory. A posteriori emissions feature distinct maxima both in winter and summer for north China, with only small variations with season for south China. The annual mean difference between a posteriori and a priori emissions is
$0.9 \mathrm{Tg} \mathrm{N} / \mathrm{yr}$ for north China (or $43 \%$ of the a priori), $0.27 \mathrm{Tg} \mathrm{N} / \mathrm{yr}$ for south China (or $20 \%$ of the a priori). The largest seasonal percentage increase in $\mathrm{NO}_{\mathrm{x}}$ emissions compared with the a priori inventory is for winter in north China (47\% increase), and for fall in south China $(30 \%$ increase).

[31] The seasonality of emissions was found not to mimic either tropospheric $\mathrm{NO}_{2}$ columns or AMFs, indicating the importance of $\mathrm{NO}_{\mathrm{x}}$ lifetime in determining the response of observed columns to local emissions. Seasonal variations of $\mathrm{NO}_{2}$ columns are displayed in Figure $7 \mathrm{e}$ and $7 \mathrm{f}$ for the north and south, respectively. Tropospheric columns derived from GOME and the model exhibit seasonality that is similar for both north and south China, with a minimum in summer and a maximum in winter attributed primarily to seasonal differences in the lifetime of $\mathrm{NO}_{\mathrm{x}}$. Stratospheric $\mathrm{NO}_{2}$ columns are lower in the south than in the north with a broad springsummer maximum, consistent with the latitudinal gradient and seasonality suggested by Wenig et al. [2004] for stratospheric $\mathrm{NO}_{2}$ columns retrieved from GOME. Seasonal variations of AMFs are presented in Figure $7 \mathrm{~g}$ and $7 \mathrm{~h}$ for north and south China respectively. Tropospheric AMFs vary in response to a number of different factors, including satellite viewing geometries, $\mathrm{NO}_{2}$ vertical profiles, surface reflectivities, clouds and aerosols. The complex interaction of those influences results in the seasonal variations of AMFs displayed in the figures.

\section{Partitioning of GOME-Derived Emissions}

[32] The a posteriori representation of $\mathrm{NO}_{\mathrm{x}}$ emissions from east China derived from GOME is significantly higher than results indicated in the a priori representation. We attempt in this section to identify the origin of the additional sources of $\mathrm{NO}_{\mathrm{x}}$. Since our analysis of GOME constrains only composite emissions, additional information is required 
(a) N.CH Monthly Emis

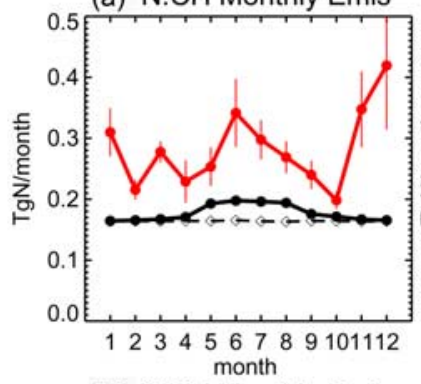

(b) S.CH Monthly Emis

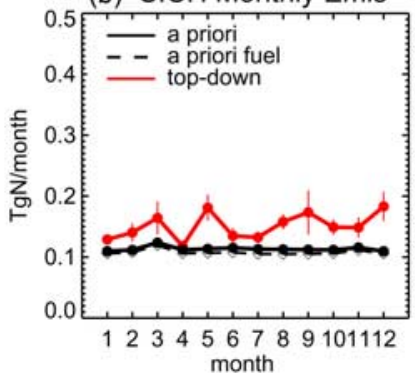

(c) N.CH Seasonal Emis

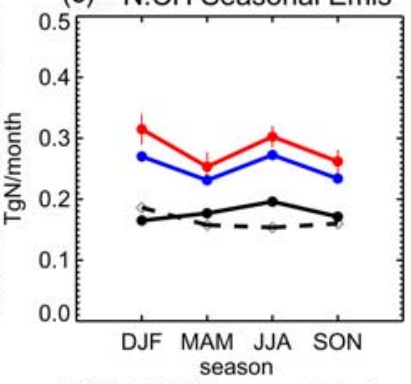

(d) S.CH Seasonal Emis

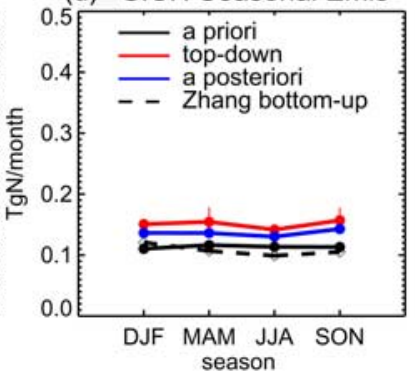

(e) N.CH Seasonal Columns

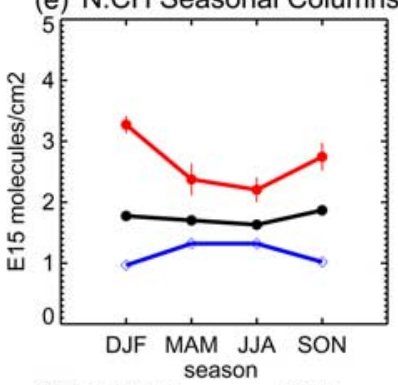

(f) S.CH Seasonal Columns

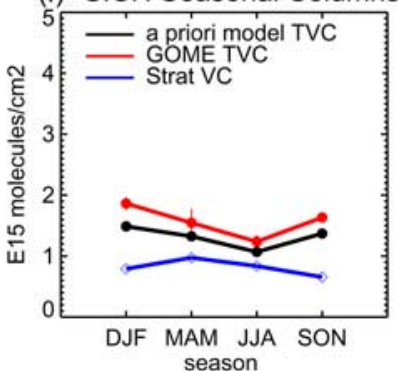

(g) N.CH Tropospheric AMF

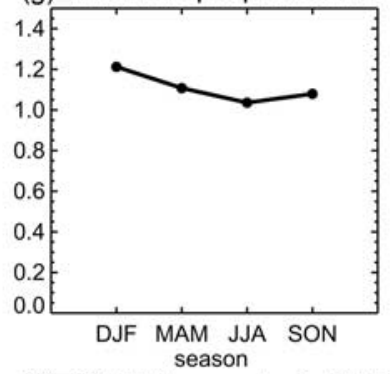

(h) S.CH Tropospheric AMF

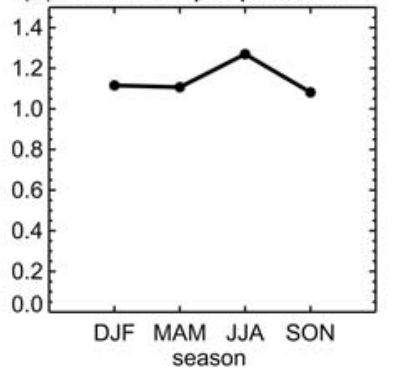

Figure 7. Monthly emissions for (a) north China $\left(100-123^{\circ} \mathrm{E}, 32-42^{\circ} \mathrm{N}\right)$ and (b) south China $(100-$ $123^{\circ} \mathrm{E}, 32-42^{\circ} \mathrm{N}$ ). The top-down emissions are displayed by red solid lines (with RMS differences as vertical thin lines), a priori emissions are displayed by black solid lines, and contributions from fuel combustion assumed in the a priori inventory are displayed by black dashed lines. Seasonal emissions for (c) north China and (d) south China. The top-down emissions are displayed by red solid lines (with RMS differences as vertical lines), the a posteriori emissions are displayed by blue solid lines, a priori emissions are displayed by black solid lines, and emissions from fuel combustion as estimated by Zhang et al. (manuscript in preparation, 2007) are displayed by black dashed lines. Seasonal variations of $\mathrm{NO}_{2}$ columns for (e) north China and (f) south China. The GOME observations are displayed by red solid lines (with RMS differences as vertical lines), the model results obtained using a priori emissions are displayed by black solid lines, and the stratospheric columns are displayed by blue solid lines. Seasonal variations of tropospheric AMFs for (g) north China and (h) south China.

to partition a posteriori $\mathrm{NO}_{\mathrm{x}}$ sources among biomass burning, fuel combustion, and microbial sources.

\subsection{Biomass Burning Emissions}

[33] We focus first on emissions from biomass burning, for which seasonality has been established in the a priori inventory based on satellite observations of fires and aerosols using data from the ATSR and TOMS instruments respectively [Duncan et al., 2003]. Most open-fire burning in east China is associated with burning of crop residues (e.g., straw) and exhibits thus a distinct seasonality determined by well-defined agriculture practices. Emissions of $\mathrm{NO}_{\mathrm{x}}$ from biomass burning peak in summer for north China following the winter wheat harvest and in fall for south China following harvest of summer rice. Since crop residues have relatively high moisture content and farmers do not normally bother to sun-dry their wastes, rural burning generally involves low temperatures and inefficient combustion, and is expected therefore to result in relatively low emissions of $\mathrm{NO}_{\mathrm{x}}$ [Wang et al., 2002]. A priori estimates for $\mathrm{NO}_{\mathrm{x}}$ emitted from biomass burning in China are very low, $0.04 \mathrm{TgN} / \mathrm{yr}$ for east China and $0.09 \mathrm{TgN} / \mathrm{yr}$ for the whole country. Streets et al. [2003] suggested a higher value for China, $0.25 \mathrm{TgN} / \mathrm{yr}$, equal to about $7 \%$ of the contribution from fuel combustion. Given the small contribution of biomass burning to total emissions of $\mathrm{NO}_{\mathrm{x}}$ in China and no clear evidence for errors in its seasonality, we adopt the seasonality represented in the a priori inventory by Duncan et al. [2003] while taking an average of the two available estimates (i.e., $0.04 \mathrm{TgN} / \mathrm{yr}$ from the a priori construction and 0.11 from Streets et al. [2003]) as our best guess for the annual magnitude of emissions from biomass burning. Emission of $\mathrm{NO}_{\mathrm{x}}$ from biomass burning in east China is thus taken as $0.08 \mathrm{TgN} / \mathrm{yr}$ in the a posteriori inventory with an uncertainty of $50 \%$, increased by about a factor of 2 from the a priori estimate, corresponding to $2 \%$ of total a posteriori emissions inferred for east China. Our rough estimate of $\mathrm{NO}_{\mathrm{x}}$ emitted from biomass burning in east China takes advantage of very low emissions of $\mathrm{NO}_{\mathrm{x}}$ from burning of crop residues as compared to emissions from fossil fuel combustion or microbial activity. This method cannot readily be generalized to other species such as $\mathrm{CO}$ and hydrocarbons for which agricultural waste burning may be more important [Fu et al., 2007].

\subsection{Fuel Combustion Emissions}

[34] Fuel sources refer to composite emissions from combustion of fossil and biofuel. These emissions are assumed in the a priori inventory as to be independent of season for China, although one might expect some variation with season associated with space heating. Streets et al. [2003] estimated a ratio of 1.2 between maximum and 


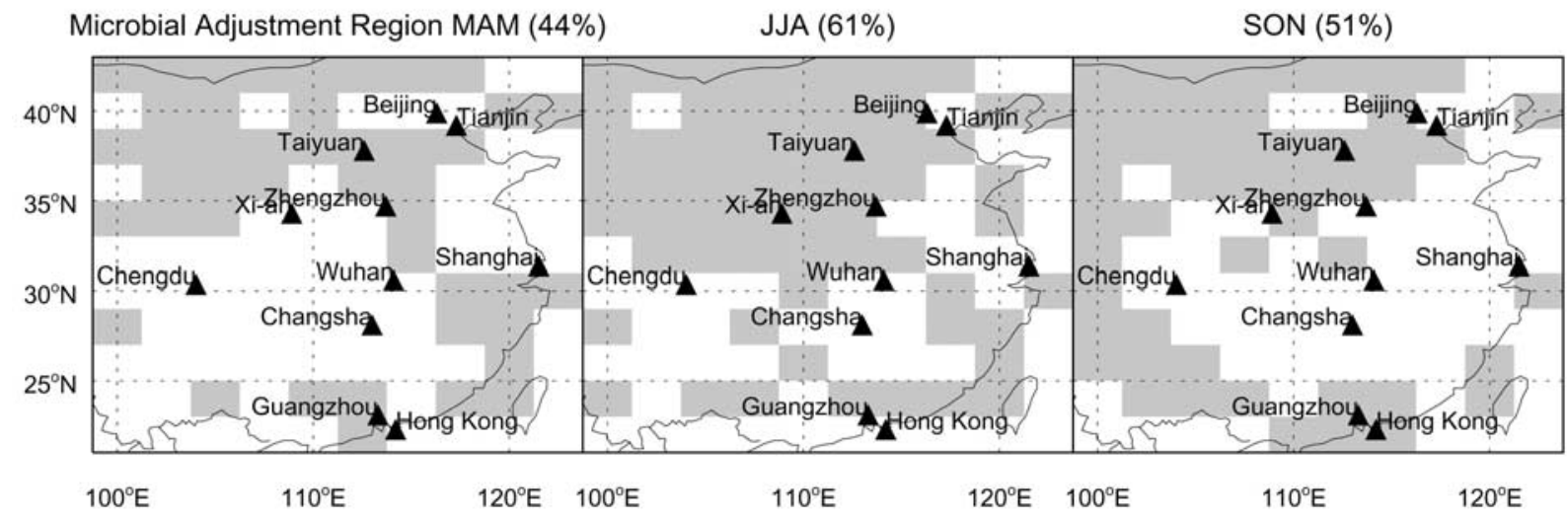

Figure 8. Spatial distribution of microbial adjustment regions (gray areas) identified for nonwinter seasons (MAM, JJA, and SON) when the uncertainty in the a priori combustion source is set as $60 \%$ (i.e., $F=60 \%)$. A number of large Chinese cities are labeled as black triangles. The percentage number listed in parentheses on top of each figure refers to area fraction of microbial adjustment regions in east China.

minimum monthly emissions associated with fuel use allowing for the dependence of stove operation on outdoor temperatures. Jaeglé et al. [2005], on the basis of their partitioning of GOME-derived emissions, derived a topdown inventory for fuel combustion sources for China in 2000. Their estimate for annual mean emissions from China is similar to that of Streets et al. [2003], but with larger month-to-month variability, suggesting a ratio of 1.4 between months with highest and lowest emissions. Jaeglé et al. [2005] attributed the higher ratio between winter and summer emissions to seasonality in energy use by industry and power generation not accounted for by Streets et al. [2003]. In a more recent study, Q. Zhang et al. $\left(\mathrm{NO}_{\mathrm{x}}\right.$ emission trends for China, 1995-2004: The view from the ground and the view from space, manuscript in preparation, 2007, hereinafter referred to as Zhang et al., manuscript in preparation, 2007) estimated interannual and monthly variations in fuel related sources of $\mathrm{NO}_{\mathrm{x}}$ for China using monthly activity data specific for each year. They estimated a ratio of 1.2 between winter and summer emissions. Zhang et al. (manuscript in preparation, 2007) presented also a reanalysis of fuel combustion sources of $\mathrm{NO}_{\mathrm{x}}$, comparing results from several different bottom-up scenarios. Their best guess scenario reflects best current knowledge with potential improvements to the analysis of Streets et al. [2003]. These improvements are applied to emission factors and to energy consumption data for which the Chinese official statistics are considered uncertain. Emissions of $\mathrm{NO}_{\mathrm{x}}$ from China derived from these scenarios vary by less than $20 \%$, with a mean value of $3.6 \mathrm{TgN} / \mathrm{yr}$ over the 3-year period of our study. The upper end of their estimates envisages higher emissions from the power and transportation sector. The lower end corresponds to a scenario in which emission factors for the industrial sector are reduced assuming a lower efficiency for combustion [Streets et al., 2006]. The detailed work of Zhang et al. (manuscript in preparation, 2007), consistent with other studies [Streets et al., 2003; Jaeglé et al., 2005], suggests that errors in bottom-up fuel combustion sources of $\mathrm{NO}_{\mathrm{x}}$ from China are likely to be constrained not to exceed $50 \%$ seasonally. The lower bound for uncertainties in the combustion inventory for $\mathrm{NO}_{\mathrm{x}}$ as compared to $\mathrm{CO}$ reflects the fundamental difference between these two species in terms of their response to temperature and the efficiency of combustion [Streets et al., 2006]. Detailed estimates for a posteriori fuel combustion and microbial sources, including variability with season, will be developed in the next section.

\subsection{Microbial Sources and Their Seasonality}

[35] We identify specific regions requiring significant adjustments for the microbial source (we refer to these regions as microbial adjustment regions in what follows) by comparing the differences between the a posteriori estimate of composite emissions (after subtracting the contribution from biomass burning) and a priori estimate of combustion sources. The comparison is made using seasonally averaged emissions for individual model grids. We consider three cases in which the uncertainties in the a priori inventory of combustion sources (denoted as F) are set as $40 \%, 50 \%$, and $60 \%$ over east China, i.e., $F=40 \%$, $50 \%$, or $60 \%$. The choice of three Fs will likely cover the uncertainty ranges for the a priori combustion source (section 5.2), minimizing the dependence of our results on a particular bottom-up inventory used in the partitioning. If composite a posteriori emissions for a given grid are higher than implied by the a priori combustion source by more than $\mathrm{F} \%$, the grid is considered as a microbial adjustment region. If the difference is less than $\mathrm{F} \%$ of the a priori combustion source or negative (i.e., the a posteriori estimate for the composite emission is lower than a priori value for the combustion emission, which occurred in about $4 \%$ of the grid elements in east China), the grid is identified as a combustion adjustment region (i.e., not a microbial adjustment region). The microbial adjustment regions identified in the most conservative case $(\mathrm{F}=60 \%)$ are presented as gray areas in Figure 8 for nonwinter seasons (the source partitioning for winter is treated differently as described below). Some representative Chinese cities (mostly provincial capitals) are labeled in Figure 8 and were found to locate generally outside of the microbial adjustment regions except in summer. The microbial adjustment regions account for 


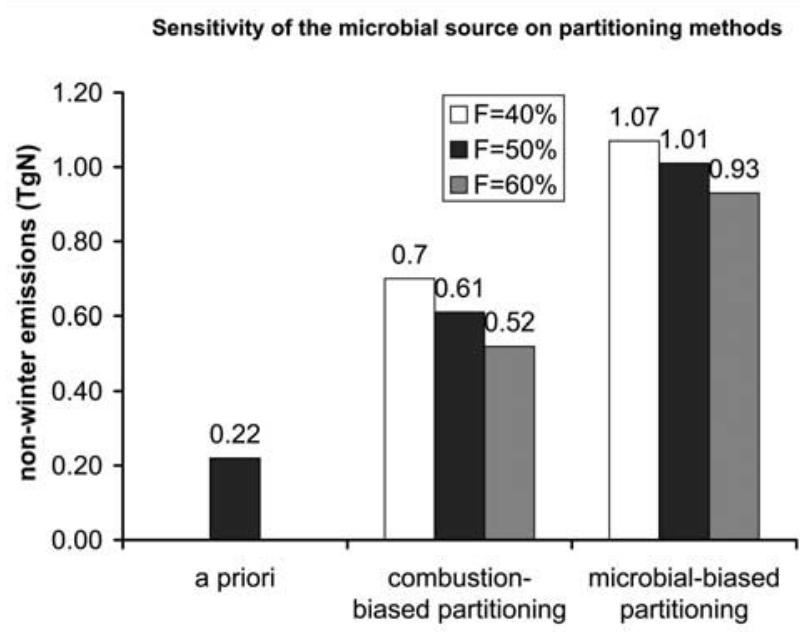

Figure 9. Comparison of the magnitude of nonwinter microbial sources over east China derived from different partitioning methods. The a priori value is also shown. See section 5.3 for description of the partitioning methods.

about $50 \%$ of east China by area, with a maximum fraction of over $60 \%$ in summer.

[36] We conduct the source partitioning for each value of F. For a combustion adjustment region, the microbial source is fixed at its a priori value while the combustion source is adjusted to match the composite a posteriori emission. For a microbial adjustment region two partitioning schemes are used. The first scheme increases the combustion source by F\%, followed by an adjustment of the microbial source to match the composite a posteriori emission; this is referred to as the combustion-biased partitioning. The second method is to adjust solely the microbial source to match the composite a posteriori emissions while holding the combustion source at its a priori value; this is called the microbial-biased partitioning. The magnitude of the microbial source is expected to be bracketed using these two partitioning methods. The microbial source resulting from the partitioning is summarized for nonwinter seasons and compared in Figure 9 for each value of $F$ and for the two partitioning methods (six cases in total). Results exceed a priori values in all cases by more than a factor 2 . Differences between cases are generally within $40 \%$. A similar magnitude of relative differences is found in results for a particular season (not shown). We choose to take the mean of all six cases listed in Figure 9 as our best guess for the a posteriori microbial source over east China in nonwinter seasons $($ mean $=0.81 \mathrm{TgN})$, with the standard deviation attributed to the uncertainties in the partitioning $(1 \sigma=0.22 \mathrm{TgN}$ or $27 \%$ of the mean). The overall uncertainty in the a posteriori microbial source is estimated as the quadratic sum of errors associated with the partitioning $(27 \%)$ and the composite emissions derived from GOME (30\%; see section 4.2). The resulting a posteriori microbial source over east China is thus $0.81 \mathrm{TgN} \pm 40 \%$ for nonwinter seasons. The a posteriori combustion source is estimated subsequently by subtracting the a posteriori microbial source from the a posteriori total (after subtracting the contribution from biomass burning), amounting to $2.55 \mathrm{TgN} \pm 32 \%$ over east China for nonwinter seasons.
[37] Our approach to partitioning is based on the assumption that the spatial distribution of composite a posteriori emissions derived from GOME is of sufficient accuracy on the scale of our model resolution $\left(2^{\circ} \times 2.5^{\circ}\right)$. This assumption might be questioned for winter when the smearing length scale of $\mathrm{NO}_{\mathrm{x}}$ [Palmer et al., 2003] is likely larger than the model resolution and the GOME pixel size [Martin et al., 2003a]. Thus we choose not to adopt this approach of source partitioning for winter. Instead, we assume that microbial activities are minimum in winter [Zheng et al., 2003] and consequently make only a small contribution to the annual total of microbial sources. In the a priori inventory, the microbial source in winter amounts to $50 \%$ of its annual average south of $30^{\circ} \mathrm{N}$ and only $7 \%$ north of $30^{\circ} \mathrm{N}$, reflecting the fact that temperatures in north China are normally close to or below the freezing point in winter. Given the a posteriori microbial source derived above for other seasons, we estimated the magnitude of this source in winter using the ratio of winter to annual mean emissions adopted from the a priori inventory. The microbial source for winter is estimated as $0.04 \mathrm{TgN} \pm 40 \%$, accounting for only $3 \%$ of the combustion source in winter $(1.17 \mathrm{TgN} \pm$ $32 \%)$.

[38] Spatial distributions of the a posteriori microbial source and combustion source are displayed in Figure 10 (middle and bottom), respectively. The a priori microbial source is shown in Figure 10 (top) for comparison. Emissions are generally higher in the north than in the south. The a posteriori microbial source is found not to correlate spatially with the a posteriori combustion source, with a correlation coefficient of less than 0.3 for all seasons $(\mathrm{n}=$ 100), consistent with the expected spatial separation of the two sources (the microbial source is most likely concentrated in rural regions with the source from combustion associated to a greater extent with urban centers), lending confidence to the partitioning method. The a posteriori microbial source, however, has a moderate spatial correlation with its a priori counterpart, the correlation coefficient reaching 0.7 in summer and 0.5 for other seasons. Spatial 

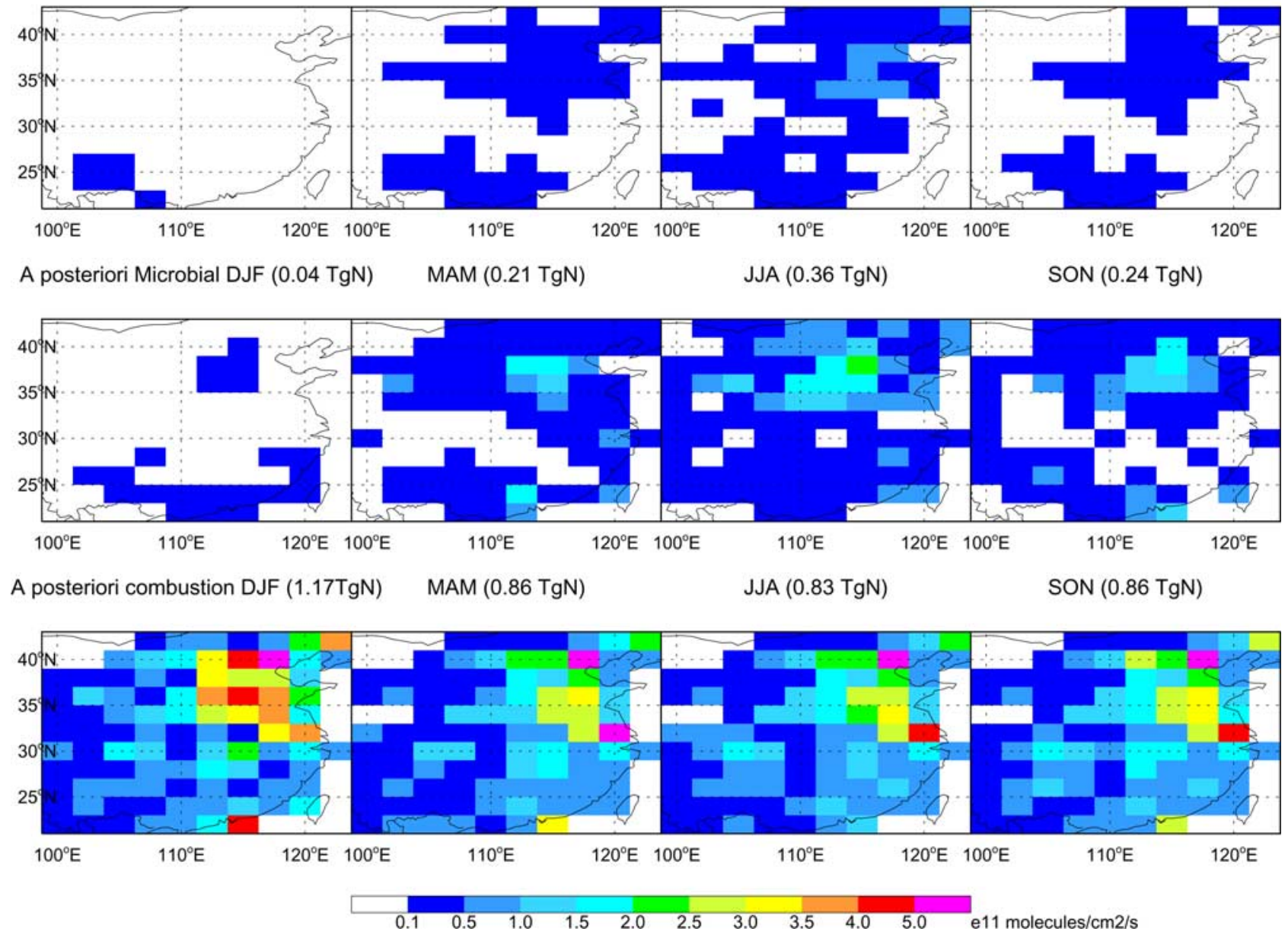

Figure 10. Spatial distribution of (top) a priori microbial emissions, (middle) a posteriori microbial emissions, and (bottom) a posteriori combustion emissions for four seasons (DJF, MAM, JJA, and SON). The number (unit is $\mathrm{TgN}$ ) listed in parentheses on top of each figure refers to total regional emissions of each source for east China in each season.

distributions of the a posteriori and a priori combustion sources are consistent $\left(\mathrm{r}^{2}=0.9\right)$ for all seasons.

[39] The a posteriori inventory for different source types is summarized and compared with the a priori inventory in Table 1. The microbial source peaks in summer $(0.36 \pm$ $0.14 \mathrm{TgN}$ ), amounting to $43 \%$ of the a posteriori combustion source derived for that season $(0.83 \pm 0.27 \mathrm{TgN})$, a factor of 3 higher than the a priori estimate of the microbial source for this time of year $(0.12 \mathrm{TgN})$. The a posteriori inventory for all of east China includes $3.72 \pm 1.2 \mathrm{TgN} / \mathrm{yr}$ from combustion ( $15 \%$ higher than the a priori estimate), and $0.85 \pm 0.34 \mathrm{TgN} / \mathrm{yr}$ from microbial activity (about a factor of 3 higher the a priori value). Annually averaged, the microbial source of $\mathrm{NO}_{\mathrm{x}}$ derived in our a posteriori inventory amounts to $23 \%$ of the combustion source for east China, significantly higher than a priori value of $7 \%$.

\subsection{Discussion and Comparison to Previous Studies}

[40] The a posteriori inventory for combustion sources exhibits a distinct peak in winter attributable to emissions from space heating, with a minimum in summer. Our results suggest a ratio of 1.4 between winter and summer emissions from combustion, consistent with the top-down analysis of Jaeglé et al. [2005]. The a posteriori combustion source derived for winter is $40 \%$ higher than the a priori value, while the difference is only a few percent for other seasons. For combustion sources in winter, the a posteriori inventory indicates an increase of $50 \%$ relative to the a priori for north China $\left(100-123^{\circ} \mathrm{E}, 32-42^{\circ} \mathrm{N}\right)$, as compared to a $20 \%$ increase to the south. Previous studies comparing GOME observations with model results found a similar pattern with $\mathrm{NO}_{2}$ columns underestimated significantly by model results in winter in the north [Ma et al., 2006; van Noije et al., 2006; Jaeglé et al., 2005]. The large discrepancy for combustion sources in winter could be attributed to errors in both the bottom-up and the top-down approach. Since the top-down and bottom-up analysis of combustion emissions is largely consistent for south China as well as for nonwinter seasons in north China, we believe that the errors should relate specifically to some phenomenon associated with the cold temperatures that prevail during winter in the north. The bias-reducing cloud screening employed in our analysis 
is unlikely to remove all the GOME scenes with temporary snow cover. Inclusion of these scenes in the retrievals would lead to an overestimate of the $\mathrm{NO}_{2}$ columns and consequently surface emissions for north China in winter. This bias was tentatively estimated to be less than $20 \%$ on the basis of our discussion in section 3.3. Another possible bias could relate to an underestimate of the magnitude of the microbial source in winter. Increasing this source by a factor of 5 in winter, however, would result in only a $5 \%$ decrease in the combustion source derived for north China. We acknowledge the difficulties with the bottom-up method in accurately evaluating the change in combustion characteristics and thus $\mathrm{NO}_{\mathrm{x}}$ emission factors associated with changes in ambient temperature. In deriving the bottom-up seasonality, Zhang et al. (manuscript in preparation, 2007) considered only the variation of fuel usage with season. They estimated that domestic coal use for north China in winter was 7 to 10 times higher than that in summer, but according to their analysis the share of the domestic sector in total $\mathrm{NO}_{\mathrm{x}}$ emissions amounts to only $8 \%$ and most of the $\mathrm{NO}_{\mathrm{x}}$ comes from power plants, industrial boilers and vehicles, for which less than $30 \%$ variations are estimated in emissions with season. It is possible that the $\mathrm{NO}_{\mathrm{x}}$ emission factors for centralized domestic heating could be underestimated in the bottom-up analysis or $\mathrm{NO}_{\mathrm{x}}$ emission factors in other sectors vary also with season.

[41] The a posteriori inventory for microbial sources displays a maximum in summer, with significant contributions also from spring and fall. The microbial source is unimportant in winter. A summer maximum might be expected given the dependence of microbial activity on temperature and is consistent with the a priori estimate for the variation of this source with season. The moisture content of soils and other media where microbial decomposition of nitrogen takes place could play an important ancillary role, however, in regulating microbial emissions of $\mathrm{NO}_{\mathrm{x}}$ and associated $\mathrm{N}_{2} \mathrm{O}$ [Hall et al., 1996]. Emission bursts, or "pulses," of $\mathrm{N}_{2} \mathrm{O}$ and $\mathrm{NO}_{\mathrm{x}}$ following wetting of dry soils have been observed both in field measurements and inferred from remote sensing [Davidson 1992; Jaeglé et al., 2004; Bertram et al., 2005]. The significant increase in microbial emissions in spring from a nearly zero background in winter could be attributed to this pulse phenomenon induced by spring rainfall as well as to a prompt response to the application of fertilizer which has been shown to induce significant emissions of $\mathrm{NO}_{\mathrm{x}}$ from soils [Bouwman et al., 2002]. Cropping practices in east China are dominated by two-crop rotation (rice or corn rotated with winter wheat) in the north with three-crop rotation (early rice-late rice-wheat) in the south [Xing, 1998]. Chemical fertilizer is applied normally in east China during spring and fall following planting of summer and winter crops respectively. The largest seasonal increase in the microbial source derived here as compared with the a priori inventory is for fall. This could be attributed to the impact of fertilizer application on emissions.

[42] The magnitude and seasonality in the a posteriori microbial emissions are consistent with the in situ measurements of Zheng et al. [2003] over a typical rice-wheat rotation system in east China during the nonwaterlogged period (November to June). Their observations showed that for fertilized plots integrated emissions of NO from March to June are 4 to 6 folds higher than emissions in winter. Our results suggest a factor of 5 difference in emissions between spring and winter. The emission factor for fertilizer-induced NO was estimated as $2.5 \%$ by Zheng et al. [2003] for their measurement period. Consumption of synthetic $\mathrm{N}$ fertilizer consumption for east China averaged about $11 \mathrm{TgN} / \mathrm{yr}$ for 1997, 1998, and 2000 [National Bureau of Statistics of China, 1998, 1999, 2001]. If we assume half of the annual fertilizer application occurs between November and June (the study period of Zheng et al. [2003]) and use the emission factor of $2.5 \%$ for the whole of east China, we would infer a microbial source of $0.22 \mathrm{TgN}$ from fertilizer application during this period. This is consistent with our a posteriori estimate of the microbial source for winter and spring combined.

[43] While our a posteriori estimate of annual microbial emissions over east China are consistent with a value of $0.94 \mathrm{TgN} / \mathrm{yr}$ inferred by Jaeglé et al. [2005] for East Asia, the seasonality of our emissions differs from their analysis. They suggested that $65 \%$ of annual total microbial emissions over East Asia originated in summer (JJA), similar to the fraction implied by the a priori inventory. In contrast, our a posteriori inventory indicates a much smaller contribution of summertime emissions to the annual total (42\%), with significant contributions from spring and fall (each of these seasons accounting for about $25 \%$ of the annual total). Jaeglé et al. [2005] separated microbial sources from combustion sources using the a priori information on the location of regions where emissions are dominated by fuel combustion. This approach works well where the relative importance of fuel combustion to the total budget of $\mathrm{NO}_{\mathrm{x}}$ is well established, as in the tropics for example or in industrialized regions, but it might be expected to introduce biases for China since emissions included in the a priori inventory may underestimate the contribution of microbial sources to total emissions of $\mathrm{NO}_{\mathrm{x}}$ [Wang et al., 2004; McElroy and Wang, 2005]. In fact, we found that according to the a priori inventory, $52 \%$ and $62 \%$ of the microbial adjustment regions identified in our most conservative case $(\mathrm{F}=60 \%$; Figure 8 ) were dominated by fuel combustion in spring and fall, respectively. If we adopted the partitioning method of Jaeglé et al. [2005], these regions would have been identified as combustion adjustment regions, leading to an underestimate of the microbial source.

\section{Concluding Remarks}

[44] Seasonal variations of tropospheric $\mathrm{NO}_{2}$ columns inferred from the GOME instrument were analyzed for a 3-year period (1997, 1998, and 2000) for east China (100$\left.123^{\circ} \mathrm{E}, 20-42^{\circ} \mathrm{N}\right)$. Scene-specific AMFs were employed in the retrieval to account for interannual variations in AMF. Zonal variations in stratospheric columns of $\mathrm{NO}_{2}$ were adopted from assimilated observations of stratospheric slant columns. Special treatments were applied to account for cloud screening in order to reduce biases in the seasonality of $\mathrm{NO}_{2}$ columns derived from GOME. We showed that tropospheric $\mathrm{NO}_{2}$ columns derived from GOME were significantly higher over east China than results obtained using a global three-dimensional chemical transport model (GEOS-Chem) with seasonal variations notably different from these assumed in the model. 
[45] The discrepancies between GOME and model results were attributed to deficiencies in the a priori inventory of surface emissions of $\mathrm{NO}_{\mathrm{x}}$. The top-down inventory of $\mathrm{NO}_{\mathrm{x}}$ emissions for east China was constructed using $\mathrm{NO}_{2}$ columns derived from GOME employing a chemical inversion that accounted for local $\mathrm{NO}_{2} / \mathrm{NO}_{\mathrm{x}}$ ratios and the $\mathrm{NO}_{\mathrm{x}}$ lifetimes obtained using the GEOS-Chem model. The present study improves on previous work by accounting explicitly for the contributions to background $\mathrm{NO}_{2}$ columns arising from nonsurface sources (lightning) and long-range transport of emissions originating outside of east China. The top-down inventory was combined subsequently with the a priori, weighted by the relative uncertainty in each, to develop an a posteriori inventory. The regional total of the a posteriori inventory for east China is $4.66 \mathrm{Tg} \mathrm{N} / \mathrm{yr}, 33 \%$ higher than the a priori value. The uncertainty in the a posteriori inventory is estimated at $30 \%$ for east China, lower than the uncertainty in either the top-down or a priori inventory. The top-down and a posteriori emission estimates derived from GOME will depend on the selected model and retrieval, specifically, on the differences between model and retrieval. To minimize biases we have treated free parameters in the retrieval in a manner consistent with the CTM; that is, the Dalhousie/SAO retrieval used in our work uses the vertical profile of $\mathrm{NO}_{2}$ simulated by the GEOS-Chem model. Among the CTMs and retrievals selected in the intercomparison work of van Noije et al. [2006], the variations of simulated and retrieved columns over east China are generally within $20 \%$. The uncertainties assigned in our work to model columns (20\%) and retrieved columns $(30 \%)$ are in agreement with those indicated by van Noije et al. [2006].

[46] Seasonal variability in emissions was evaluated for regions north and south of the Yangtze River, identified here as north and south China. A posteriori emissions feature maxima both in winter and summer for north China, with only weak seasonality for south China. The seasonal variations in emissions were shown not to mimic simply either observed tropospheric $\mathrm{NO}_{2}$ columns or AMFs, but to reflect the importance of the $\mathrm{NO}_{\mathrm{x}}$ lifetime in determining the response of observed columns to local emissions. The validity of the a posteriori inventory was supported by comparison of model results with measurements of nitrate wet deposition at two Chinese remote sites from EANET and with surface concentrations of total reactive nitrogen $\left(\mathrm{NO}_{\mathrm{y}}\right)$ observed at a rural site in east China.

[47] We presented a simple, empirical, method to partition composite emissions of $\mathrm{NO}_{\mathrm{x}}$ derived from GOME among biomass burning, fuel combustion and microbial emissions over east China. Adopting a priori knowledge of the dependence of emission factors for $\mathrm{NO}_{\mathrm{x}}$ on temperature and on the efficiency of combustion, we concluded that sources of $\mathrm{NO}_{\mathrm{x}}$ emitted from open-fire burning of crop residues in China were unlikely to play a significant role in the overall budget of $\mathrm{NO}_{\mathrm{x}}$. The a posteriori estimate for this source $(0.08 \mathrm{TgN} / \mathrm{yr} \pm 50 \%)$ is about a factor of 2 higher than the a priori estimate, but accounts for only $2 \%$ of total a posteriori emissions for east China. Specific regions requiring significant adjustments in the magnitude of the microbial source were identified as a function of the uncertainty (denoted as F) in the a priori combustion inventory by comparing differences between the a posteriori estimate of composite emissions (after subtracting the contribution from biomass burning) and the a priori estimate of combustion sources. The uncertainty in fuel combustion sources in China has been estimated as about $50 \%$ by previous bottom-up and top-down studies [Streets et al., 2003; Jaeglé et al., 2005; Zhang et al., manuscript in preparation, 2007]. We conducted the source attribution for three values of $F$ $(40 \%, 50 \%$, and $60 \%)$, taking the mean results as our a posteriori estimate of emissions. The resulting a posteriori inventory of $3.72 \mathrm{TgN} / \mathrm{yr} \pm 32 \%$ from fuel combustion for east China is about $15 \%$ higher than the a priori value assumed in the GEOS-Chem model. The combustion source of $\mathrm{NO}_{\mathrm{x}}$ derived here displays a maximum in winter with a minimum in summer, in contrast to the weak seasonality indicated by the bottom-up approach. The a posteriori inventory of microbial sources implies a source of $0.85 \mathrm{TgN} / \mathrm{yr} \pm 40 \%$ for east China, a factor of 3 higher than the a priori inventory based on the algorithm of Yienger and Levy [1995], amounting to $23 \%$ of the fuel combustion source for the region. The microbial source is unimportant in winter. It peaks in summer, accounting for as much as $43 \%$ of the combustion source for that season, and is significant also in spring and fall. The seasonality of microbial sources derived here is attributed to the timing of fertilizer application and to the influence of seasonally variable environmental factors, notably temperature and precipitation. Our analysis, based on multiple-year results of GOME observations, suggests that microbially mediated decomposition of nitrogen processed through the human/animal/agriculture food chain (including notably the response to application of chemical fertilizer) is a significant source of $\mathrm{NO}_{\mathrm{x}}$ for east China, lending support to conclusions derived earlier by Wang et al. [2004] and McElroy and Wang [2005].

[48] Acknowledgments. We thank H. Eskes and F. K. Boersma for providing the assimilated stratospheric $\mathrm{NO}_{2}$ data that resulted from collaboration between researchers at KNMI and the BIRA/IASB group in Brussels. We thank F. K. Boersma and Daniel Jacob for helpful discussion and EANET for providing measurements of nitrate wet deposition in China.

\section{References}

Alexander, B., J. Savarino, C. C. W. Lee, R. J. Park, D. J. Jacob, M. H. Thiemens, Q. B. Li, and R. M. Yantosca (2005), Sulfate formation in seasalt aerosols: Constraints from oxygen isotopes, J. Geophys. Res., 110, D10307, doi:10.1029/2004JD005659

Benkovitz, C. M., M. T. Scholtz, J. Pacyna, L. Tarrason, J. Dignon, E. C. Voldner, P. A. Spiro, J. A. Logan, and T. E. Graedel (1996), Global gridded inventories for anthropogenic emissions of sulfur and nitrogen, J. Geophys. Res., 101, 29,239-29,253.

Bertram, T. H., A. Heckel, A. Richter, J. Burrows, and R. C. Cohen (2005), Satellite measurements of daily variations in soil $\mathrm{NO}_{\mathrm{x}}$ emissions, Geophys. Res. Lett., 32, L24812, doi:10.1029/2005GL024640.

Bey, I., et al. (2001), Global modelling of tropospheric chemistry with assimilated meteorology: Model description and evaluation, J. Geophys. Res., 106, 23,073-23,095.

Boersma, K. F., H. J. Eskes, and E. J. Brinksma (2004), Error analysis for troposheric $\mathrm{NO}_{2}$ retrieval from space, J. Geophys. Res., 109, D04311, doi:10.1029/2003JD003962.

Bouwman, A. F., L. J. M. Boumans, and N. H. Batjes (2002), Emissions of $\mathrm{N}_{2} \mathrm{O}$ and NO from fertilized fields: Summary of available measurement data, Global Biogeochem. Cycles, 16(4), 1058, doi:10.1029/ 2001GB001811.

Brown, S. S., et al. (2006), Variability in nocturnal nitrogen oxide processing and its role in regional air quality, Science, 311, 67-70, doi:10.1126/ science. 1120120

Burrows, J. P., et al. (1999), The Global Ozone Monitoring Experiment (GOME): Mission concept and first scientific results, J. Atmos. Sci., 56, 151-175.

Chance, K., P. Palmer, R. J. D. Spurr, R. V. Martin, T. P. Kurosu, and D. J. Jacob (2000), Satellite observations of formaldehyde over North America from GOME, Geophys. Res. Lett., 27, 3461-3464. 
Davidson, E. A. (1992), Pulses of nitric oxide and nitrous oxide flux following wetting of dry soil: An assessment of probable sources and importance relative to annual fluxes, Ecol. Bull., 42, 149-155.

Dentener, F. J., and P. J. Crutzen (1993), Reaction of $\mathrm{N}_{2} \mathrm{O}_{5}$ on tropospheric aerosols: Impact on the global distributions of $\mathrm{NO}_{\mathrm{x}}, \mathrm{O}_{3}$, and $\mathrm{OH}$ J. Geophys. Res., 98, 7149-7162.

Duncan, B. N., R. V. Martin, A. C. Staudt, R. Yevich, and J. A. Logan (2003), Interannual and seasonal variability of biomass burning emissions constrained by satellite observations, J. Geophys. Res., 108(D2), 4100, doi:10.1029/2002JD002378.

Environmental Protection Agency (1989), The 1985 NAPAP emission inventory (version 2); Development of the annual data and modeler's tapes, EPA Rep.-600/7-89-012a, Research Triangle Park, N. C.

Evans, M. J., and D. J. Jacob (2005), Impact of new laboratory studies of $\mathrm{N}_{2} \mathrm{O}_{5}$ hydrolysis on global model budgets of tropospheric nitrogen oxides, ozone, and OH, Geophys. Res. Lett., 32, L09813, doi:10.1029/ 2005GL022469.

Fairlie, T. D., D. J. Jacob, and R. J. Park (2007), The impact of transpacific transport of mineral dust in the United States, Atmos. Environ., 41(6), $1251-1266$

Fiore, A. M., D. J. Jacob, I. Bey, R. M. Yantosca, B. D. Field, and J. G. Wilkinson (2002), Background ozone over the United States in summer: Origin and contribution to pollution episodes, J. Geophys. Res., 107(D15), 4275, doi:10.1029/2001JD000982.

Fu, T.-M., D. J. Jacob, P. I. Palmer, K. Chance, Y. X. Wang, B. Barletta, D. R. Blake, J. C. Stanton, and M. J. Pilling (2007), Space-based formaldehyde measurements as constraints on volatile organic compound emissions in East and South Asia, J. Geophys. Res., doi:10.1029/ 2006JD007853, in press.

Hall, S. J., P. A. Matson, and P. M. Roth (1996), NO emissions from soil: Implications for air quality modeling in agricultural regions, Annu. Rev. Energy Environ., 21, 311-346.

Irie, H., et al. (2005), Evaluation of long-term tropospheric $\mathrm{NO}_{2}$ data obtained by GOME over East Asia in 1996-2002, Geophys. Res. Lett., 32 , L11810, doi:10.1029/2005GL022770.

Jacob, D. J. (2000), Heterogeneous chemistry and tropospheric ozone, Atmos. Environ., 34, 131-159.

Jacob, D. J., et al. (1993), Simulation of summertime ozone over North America, J. Geophys. Res., 98, 14,797-14,816.

Jaeglé, L., et al. (2004), Satellite mapping of rain-induced nitric oxide emissions from soils, J. Geophys. Res., 109, D21310, doi:10.1029/ 2004JD004787

Jaeglé, L., L. Steinberger, R. V. Martin, and K. Chance (2005), Global partitioning of $\mathrm{NO}_{\mathrm{x}}$ sources using satellite observations: Relative roles of fossil fuel combustion, biomass burning and soil emissions, Faraday Disc., 130, 407-423.

Koelemeijer, R. B. A., J. F. de Haan, and P. Stammes (2003), A database of spectral surface reflectivity in the range $335-772 \mathrm{~nm}$ derived from 5.5 years of GOME observations, J. Geophys. Res., 108(D2), 4070, doi:10.1029/2002JD002429.

Kurosu, T. P., K. Chance, and R. J. D. Spurr (1999), CRAG-Cloud Retrieval Algorithm for the European Space Agency's Global Ozone Monitoring Experiment, ESA WPP-161, pp. 513-521, Eur. Space and Technol. Cent., Noordwijk, The Netherlands.

Lee, D. S., et al. (1997), Estimates of global $\mathrm{NO}_{\mathrm{x}}$ emissions and their uncertainties, Atmos. Environ., 31, 1735-1749.

Leue, C., M. Wenig, T. Wagner, O. Klimm, U. Platt, and B. Jahne (2001), Quantitative analysis of $\mathrm{NO}_{\mathrm{x}}$ emissions from GOME satellite image sequences, J. Geophys. Res., 106, 5493-5505.

Li, Q., D. J. Jacob, R. Park, Y. Wang, C. L. Heald, R. Hudman, R. M. Yantosca, R. V. Martin, and M. Evans (2005), North American pollution outflow and the trapping of convectively lifted pollution by upper-level anticyclone, J. Geophys. Res., 110, D10301, doi:10.1029/2004JD005039.

Logan, J. A. (1983), Nitrogen oxides in the troposphere: Global and regional budgets, J. Geophys. Res., 88, 10,785-10,807.

Ma, J. Z., A. Richter, J. P. Burrows, H. Nüß, and J. A. van Aardenne (2006), Comparison of model-simulated tropospheric $\mathrm{NO}_{2}$ over China with GOME-satellite data, Atmos. Environ., 40, 593-604.

Martin, R. V., et al. (2002a), Interpretation of TOMS observations of tropical tropospheric ozone with a global model and in-situ observations, J. Geophys. Res., 107(D18), 4351, doi:10.1029/2001JD001480.

Martin, R. V., et al. (2002b), An improved retrieval of tropospheric nitrogen dioxide from GOME, J. Geophys. Res., 107(D20), 4437, doi:10.1029/ 2001JD001027.

Martin, R. V., D. J. Jacob, K. Chance, T. P. Kurosu, P. I. Palmer, and M. J. Evans (2003a), Global inventory of nitrogen oxide emissions constrained by space-based observations of $\mathrm{NO}_{2}$ columns, J. Geophys. Res., 108(D17), 4537, doi:10.1029/2003JD003453.

Martin, R. V., D. J. Jacob, R. M. Yantosca, M. Chin, and P. Ginoux (2003b), Global and regional decreases in tropospheric oxidants from photoche- mical effects of aerosols, J. Geophys. Res., 108(D3), 4097, doi:10.1029/ 2002JD002622.

Martin, R. V., D. D. Parrish, T. B. Ryerson, D. K. Nicks Jr., K. Chance, T. P. Kurosu, D. J. Jacob, E. D. Sturges, A. Fried, and B. P. Wert (2004), Evaluation of GOME satellite measurements of tropospheric $\mathrm{NO}_{2}$ and $\mathrm{HCHO}$ using regional data from aircraft campaigns in the southeastern United States, J. Geophys. Res., 109, D24307, doi:10.1029/ 2004JD004869.

Martin, R. V., C. E. Sioris, K. Chance, T. B. Ryerson, T. H. Bertram, P. J. Wooldridge, R. C. Cohen, J. A. Neuman, A. Swanson, and F. M. Flocke (2006), Evaluation of space-based constraints on global nitrogen oxide emissions with regional aircraft measurements over and downwind of eastern North America, J. Geophys. Res., 111, D15308, doi:10.1029/ 2005JD006680.

McElroy, M. B., and Y. X. Wang (2005), Human and animal wastes: Implications for atmospheric $\mathrm{N}_{2} \mathrm{O}$ and $\mathrm{NO}_{\mathrm{x}}$, Global Biogeochem. Cycles, 19, GB2008, doi:10.1029/2004GB002429.

Millet, D. B., et al. (2006), Formaldehyde distribution over North America: Implications for satellite retrievals of formaldehyde columns and isoprene emission, J. Geophys. Res., 111, D24S02, doi:10.1029/2005JD006853.

National Bureau of Statistics of China (1998), China Statistical Yearbook 1998, China Stat. Press, Beijing.

National Bureau of Statistics of China (1999), China Statistical Yearbook 1999, China Stat. Press, Beijing.

National Bureau of Statistics of China (2001), China Statistical Yearbook 2001, China Stat. Press, Beijing.

Palmer, P. I., D. J. Jacob, K. Chance, R. V. Martin, R. J. D. Spurr, T. P. Kurosu, I. Bey, R. Yantosca, A. Fiore, and Q. Li (2001), Air mass factor formulation for spectroscopic measurements from satellites: Application to formaldehyde retrievals from the Global Ozone Monitoring Experiment, J. Geophys. Res., 106, 14,539-14,550.

Palmer, P. I., D. J. Jacob, A. M. Fiore, R. V. Martin, K. Chance, and T. P. Kurosu (2003), Mapping isoprene emissions over North America using formaldehyde column observations from space, J. Geophys. Res., 108(D6), 4180, doi:10.1029/2002JD002153.

Park, R. J., D. J. Jacob, M. Chin, and R. V. Martin (2003), Sources of carbonaceous aerosols over the United States and implications for natural visibility conditions, J. Geophys. Res., 108(D12), 4355, doi:10.1029/ 2002JD003190.

Park, R. J., D. J. Jacob, B. D. Field, R. M. Yantosca, and M. Chin (2004), Natural and transboundary pollution influences on sulfate-nitrateammonium aerosols in the United States: Implications for policy, J. Geophys. Res., 109, D15204, doi:10.1029/2003JD004473.

Pickering, K. E., Y. S. Wang, W. K. Tao, C. Price, and J. F. Muller (1998), Vertical distributions of lightning $\mathrm{NO}_{\mathrm{x}}$ for use in regional and global chemical transport models, J. Geophys. Res., 103, 31,203-31,216.

Potter, C. S., P. A. Matson, P. M. Vitousek, and E. A. Davidson (1996), Process modeling of controls on nitrogen trace gas emissions from soils worldwide, J. Geophys. Res., 101, 1361-1378.

Price, C., and D. Rind (1992), A simple lightning parameterization for calculating global lightning distributions, J. Geophys. Res., 97, 99199933.

Richter, A., and J. P. Burrows (2002), Tropospheric $\mathrm{NO}_{2}$ from GOME measurements, Adv. Space Res., 29, 1673-1683.

Richter, A., and T. Wagner (2001), Diffuser plate spectral structures and their influence on GOME slant columns, Technical Note January 2001, Inst. Ecol. Physics, Bremen, Germany. (Available at http://www-iup. physik.uni-bremen.de/gome/data/diffuser gome.pdf)

Richter, A., J. P. Burrows, H. Nüß, C. Granier, and U. Niemeier (2005), Increase in tropospheric nitrogen dioxide levels over China observed from space, Nature, 437, 129-132.

Sinton, J. E., and D. G. Fridley (2000), What goes up: Recent trends in China's energy consumption, Energy Policy, 28, 671-687.

Spurr, R. J. D. (2002), Simultaneous derivation of intensities and weighting functions in a general pseudo-spherical discrete ordinate radiative transfer treatment, J. Quant. Spectrosc. Radiat. Transfer, 75, 129-175.

Spurr, R. J. D., T. P. Kurosu, and K. V. Chance (2001), A linearized discrete ordinate radiative transfer model for atmospheric remote sensing retrieval, J. Quant. Spectrosc. Radiat. Transfer, 68, 689-735.

Streets, D. G., et al. (2003), An inventory of gaseous and primary aerosol emissions in Asia in the year 2000, J. Geophys. Res., 108(D21), 8809, doi:10.1029/2002JD003093.

Streets, D. G., Q. Zhang, L. Wang, K. He, J. Hao, Y. Wu, Y. Tang, and G. R. Carmichael (2006), Revisiting China's CO emissions after TRACE-P: Synthesis of inventories, atmospheric modeling, and observations, J. Geophys. Res., 111, D14306, doi:10.1029/2006JD007118.

van $\operatorname{der}$ A, R. J., D. H. M. U. Peters, H. Eskes, K. F. Boersma, M. Van Roozendael, I. De Smedt, and H. M. Kelder (2006), Detection of the trend and seasonal variation in tropospheric $\mathrm{NO}_{2}$ over China, J. Geophys. Res., 111, D12317, doi:10.1029/2005JD006594. 
van Noije, T. P. C., et al. (2006), Multi-model ensemble simulations of tropospheric $\mathrm{NO}_{2}$ compared with GOME retrievals for the year 2000 Atmos. Chem. Phys. Disc., 6, 2965-3047.

Wang, T., T. F. Cheung, Y. S. Li, X. M. Yu, and D. R. Blake (2002), Emission characteristics of $\mathrm{CO}, \mathrm{NO}_{\mathrm{x}}, \mathrm{SO}_{2}$ and indications of biomass burning observed at a rural site in eastern China, J. Geophys. Res., 107(D12), 4157, doi:10.1029/2001JD000724.

Wang, Y., D. J. Jacob, and J. A. Logan (1998), Global simulation of tropospheric $\mathrm{O}_{3}-\mathrm{NO}_{x}$-hydrocarbon chemistry 1 . Model formulation, J. Geophys. Res., 103(D9), 10,713-10,726.

Wang, Y. X., M. B. McElroy, T. Wang, and P. I. Palmer (2004), Asian emissions of $\mathrm{CO}$ and $\mathrm{NO}_{\mathrm{x}}$ : Constraints from aircraft and Chinese station data, J. Geophys. Res., 109, D24304, doi:10.1029/2004JD005250.

Weatherhead, E. C., et al. (1998), Factors affecting the detection of trends: Statistical considerations and applications to environmental data J. Geophys. Res., 103, 17,149-17,161

Wenig, M., S. Kühl, S. Beirle, E. Bucsela, B. Jähne, U. Platt, J. Gleason, and T. Wagner (2004), Retrieval and analysis of stratospheric $\mathrm{NO}_{2}$ from the Global Ozone Monitoring Experiment, J. Geophys. Res., 109, D04315, doi:10.1029/2003JD003652.
Wild, O., Q. Zhu, and M. J. Prather (2000), Fast-J: Accurate simulation of in- and below-cloud photolysis in global chemical models, J. Atmos. Chem., 37, 245-282.

Xing, G. X. (1998), $\mathrm{N}_{2} \mathrm{O}$ emissions from croplands in China, Nutrient Cycling Agroecosyst., 52, 249-254.

Yienger, J. J., and H. Levy II (1995), Empirical model of global soilbiogenic $\mathrm{NO}_{\mathrm{x}}$ emissions, J. Geophys. Res., 100, 11,447-11,464.

Zheng, X., Y. Huang, Y. Wang, and M. Wang (2003), Seasonal characteristics of nitric oxide emission from a typical rice-wheat rotation during the non-waterlogged period, Global Change Biol., 9, 219-227.

T.-M. Fu, M. B. McElroy, and Y. Wang, Division of Engineering and Applied Sciences and Department of Earth and Planetary Sciences, Harvard University, Cambridge, MA 02138, USA. (wang3@fas.harvard.edu)

R. V. Martin, Department of Physics and Atmospheric Science, Dalhousie University, Halifax, NS, Canada B3H 3J5.

D. G. Streets and Q. Zhang, Decision and Information Sciences Division, Argonne National Laboratory, Argonne, IL 60439, USA. 